University of South Florida

DIGITAL COMMONS

Digital Commons @ University of

@ UNIVERSITY OF SOUTH FLORIDA

South Florida

10-1993

\title{
A Description of COADS Surface Meteorological Fields and the Implied Sverdrup Transports for the Atlantic Ocean from $30^{\circ} \mathrm{S}$ to $60^{\circ} \mathrm{N}$
}

Dennis A. Mayer

Atlantic Oceanographic and Meteorological Laboratory

Robert H. Weisberg

University of South Florida, weisberg@marine.usf.edu

Follow this and additional works at: https://digitalcommons.usf.edu/msc_facpub

Part of the Marine Biology Commons

\section{Scholar Commons Citation}

Mayer, Dennis A. and Weisberg, Robert H., "A Description of COADS Surface Meteorological Fields and the Implied Sverdrup Transports for the Atlantic Ocean from $30^{\circ} \mathrm{S}$ to $60^{\circ} \mathrm{N}$ " (1993). Marine Science Faculty Publications. 145.

https://digitalcommons.usf.edu/msc_facpub/145

This Article is brought to you for free and open access by the College of Marine Science at Digital Commons @ University of South Florida. It has been accepted for inclusion in Marine Science Faculty Publications by an authorized administrator of Digital Commons @ University of South Florida. For more information, please contact digitalcommons@usf.edu. 


\title{
A Description of COADS Surface Meteorological Fields and the Implied Sverdrup Transports for the Atlantic Ocean from $30^{\circ} \mathrm{S}$ to $60^{\circ} \mathrm{N}$
}

\author{
DENNIS A. MAYER \\ National Oceanic and Atmospheric Administration, Atlantic Oceanographic and Meteorological Laboratory, Miami, Florida \\ ROBERT H. WEISBERG \\ Department of Marine Science, University of South Florida, St. Petersburg, Florida
}

(Manuscript received 20 April 1992, in final form 9 November 1992)

\begin{abstract}
Using COADS data spanning 1947-1988, we describe the regional nature of the Atlantic Ocean wind-driven circulation between $30^{\circ} \mathrm{S}$ and $60^{\circ} \mathrm{N}$ and its annual and interannual variability. The Sverdrup streamfunction defines the circulation gyres. Our focus is on three central gyres: the Northern Hemisphere anticyclonic subtropical gyre, the cyclonic tropical gyre just north of the equator, and the clockwise equatorial gyre straddling the equator. This rendition of the Sverdrup streamfunction, computed with constant drag coefficient and air density, compares favorably with that from other climatologies. In the Straits of Florida, analyses suggest that differences between the annual cycle in Sverdrup transport and observations may be due to regional winds farther north. In the tropical gyre, the Sverdrup circulation argues against a continuous western boundary current transporting water from the equatorial region into the Caribbean in boreal winter, bringing to question the mechanisms for the known interhemisphere and intergyre exchanges of heat and mass. A conceptual model is proposed involving two stages. First, the western boundary current closing the clockwise equatorial gyre is instrumental in storing heat and mass between the North Equatorial Countercurrent ridge and the North Equatorial Current trough in boreal summer. Transport farther north, across the tropical gyre and into the subtropical gyre, in boreal winter is then accomplished by Ekman transport, as the seasonal change in wind-stress torque deepens the thermocline, thus allowing for vortex stretching and northward Sverdrup transport over the region of warmest waters. Once in the subtropical gyre, the Ekman transport continues to be northward despite the fact that the Sverdrup transport reverses to be southward. Annual and interannual variability is addressed by examining the spectrum of curl and its regional distribution. Outside the tropics and the Sargasso Sea, interannual exceeds annual variability by at least a factor of 1.5 . A pentadal analysis in the subtropical gyre indicates that windstress curl was not a major factor in the density structure differences reported between 1955-1959 and 19701974; hence, these require other explanations.
\end{abstract}

\section{Introduction}

Herein, we describe the Sverdrup wind-driven circulation, the surface atmosphere pressure $\left(P_{b}\right)$, and the sea surface temperature (SST) fields from $30^{\circ} \mathrm{S}$ to $60^{\circ} \mathrm{N}$ in the Atlantic Ocean, using four decades of COADS (Comprehensive Ocean-Atmosphere Data Set) data (Woodruff et al. 1987) analyzed from 1947 through 1988. Curl and divergence (div) fields are derived from the surface wind stress. These fields are used to compute the Ekman and the geostrophic components of the vertically integrated Sverdrup mass flux and the Sverdrup streamfunction fields. The latter forms the basis for revisiting questions regarding intergyre exchange. We focus on the three central gyres in the Atlantic Ocean: the large subtropical (anticyclonic) gyre, the tropical (cyclonic) gyre just to the

Corresponding author address: Mr. Dennis A. Mayer, NOAA/ AOML/PhOD, 4301 Rickenbacker Causeway, Miami, FL 33149. north of the equator, and the clockwise equatorial gyre that straddles the equator. Inferences are drawn based on the annual cycle of the Sverdrup transport fields and the annual and interannual variability of the windstress curl.

To endow the COADS-derived fields with some credibility, we have made integral comparisons of the stress components at selected latitudes and the total Sverdrup streamfunction with other climatologies described in Böning et al. (1991).

In the subtropical gyre, climatological winds suggest maxima in southward transport near $30^{\circ} \mathrm{N}$ in both the summer and winter, ranging respectively from about $30 \mathrm{~Sv}$ to greater than $40 \mathrm{~Sv}\left(1 \mathrm{~Sv} \equiv 1 \times 10^{6} \mathrm{~m}^{3} \mathrm{~s}^{-1}\right)$, with a collapse of the transport in the fall to about half the maximum. Direct observational evidence of this annual transport signal remains elusive (Lee et al. 1990). In the Straits of Florida, the fluctuation range of the annual transport is about $6 \mathrm{~Sv}$ (Rosenfeld et al. 1989), but a broad maximum occurs only in the spring and summer, with a rapid collapse in the fall. The an- 
nual transport cycle in the Straits of Florida is strongly correlated with sea level difference (SLD), Mayer and Maul (1991). Evidence is presented here suggesting that regional winds north of the straits are coherent with SLD, thereby providing a mechanism for the observed variability.

Intergyre exchange of heat and mass between the subtropical gyre and its northern (subpolar) and southern (tropical) neighbors is a principal issue in attempting to account for the interhemisphere distribution of water masses. In the tropical gyre, particular interest is focused on the issue of western boundary current closure. The Sverdrup circulation implies a southeastward boundary current (SEBC) throughout the year, which is opposite to the notion of a continuous northwestward boundary flow into the Caribbean during boreal winter. As described in the discussion, the COADS climatological fields suggest a resolution of this conundrum that utilizes different physical mechanisms during different seasons to effect an interhemisphere and intergyre exchange of mass and heat. This is consistent with Schmitz and Richardson (1991), who suggest that surface flow from the eastern South Atlantic toward the Caribbean is not restricted to the northern Brazil coast and that much of the South Atlantic contribution to the transport of the Florida Current does not flow directly by the North Brazil Current. On the northern side of the subtropical gyre, Ekman transport is not important for the exchange of mass and heat with the subpolar gyre. Warm core rings (Brown et al. 1986) and other eddies that transport salinity and temperature anomalies represent plausible exchange mechanisms on the northern side of the Gulf Stream.

Interannual variability is addressed by examining the regional distribution of curl for frequencies less than a year and for six pentads from 1955 to 1984 , along with zonal integrals of curl (Sverdrup transport) over this period. These are compared with observations of long-term changes in the water mass characteristics in the subtropical gyre. For example, the Levitus (1989) comparison of water mass characteristics between the 1955-1959 and 1970-1974 pentads revealed a shoaling of density surfaces, suggesting that a decrease in convection played a role in modifying the thermohaline structure of the upper few hundred meters of the subtropics and that the Gulf Stream transport may have been lower during 1970-1974 than during 1955-1959. However, the extent to which interannual variability of convective processes influences the water masses in the subtropics and Gulf Stream transport is not at all clear. Talley and Raymer (1982) note that late winter convective formation in the north-central Sargasso Sea of $18^{\circ} \mathrm{C}$ Water ceased from 1972 to 1975 . Worthington (1977) reported that one of the lowest baroclinic transports ever observed for the Gulf Stream occurred after the mild winter of $1974 / 75$. In contrast, Leetmaa (1977) and Worthington (1977) suggested that, after the severe winter of $1976 / 77$ in early spring, the baroclinic transport of the Gulf Stream was among the highest ever observed, significantly changing the topography of the main thermocline with newly formed $18^{\circ} \mathrm{C}$ Water. The COADS analysis suggests that something other than large-scale wind-stress curl must be invoked to account for these interannual variations.

The paper is organized as follows. Section 2 describes the data and the computations of the derivative fields. The boreal winter and summer mean fields for surface atmospheric pressure $P_{b}$, SST, and the surface windstress derivative fields (div and curl) are given in section 3. Section 4 outlines the Sverdrup calculations, makes comparisons with existing climatologies, and describes the annual cycle of the Sverdrup transport fields. Annual and interannual variability of the curl field is described in section 5. Section 6 discusses the implications of the COADS fields on the circulation within the analysis domain $\left(30^{\circ} \mathrm{S}-60^{\circ} \mathrm{N}, 96^{\circ} \mathrm{W}-16^{\circ} \mathrm{E}\right)$. Finally, section 7 summarizes the questions raised and the hypotheses presented.

\section{Data}

Four sequences of conditioned fields were created from COADS (Slutz et al. 1985) for the Atlantic Ocean. These are atmospheric pressure $\left(P_{b}\right)$, sea surface temperature (SST), and the two components of wind pseudostress (WU and WV) spanning a 42-year period from 1947 through 1988. Temporal and spatial resolutions are monthly and $2^{\circ} \times 2^{\circ}$, respectively, in the analysis domain.

Monthly summaries trimmed groups (MSTG) 3, 4, and 5 from COADS Release 1 (Slutz et al. 1985) plus COADS interim products provided the database for generating the conditioned fields: $P_{b}$, SST, WU, and WV. Although data are available beginning in 1854 , the year 1947 was chosen to begin the analyses, because in this and subsequent years more than half of the $2^{\circ}$ $\times 2^{\circ}$ boxes contain data (Fig. 1). Data poor regions can be identified by contouring the spatial sampling patterns averaged over a representative decade (Fig. 2 ). A smooth and fill conditioning algorithm (essentially a low-pass filter) was applied to the data. The net effect was assessed by operating with the conditioning algorithm on a two-dimensional field the size of the Atlantic Ocean region composed of unit amplitudes and random phases. Using a 2D Fourier transform, as in Mayer et al. (1990), the energy rejection characteristics of the smoothed random field were determined to be approximately $3 \mathrm{~dB}$ (half-power point) at 1000 $\mathrm{km}$ and $6 \mathrm{~dB}$ (half amplitude) at $700 \mathrm{~km}$. This provides some measure of how the wavenumber content of the 2D field has been compromised. No additional filtering was performed in the time domain.

Curl and div fields were computed at the center of each $2^{\circ} \times 2^{\circ}$ box. After adjusting the local zonal distance for latitude, a least-squares plane was fit to a 9- 


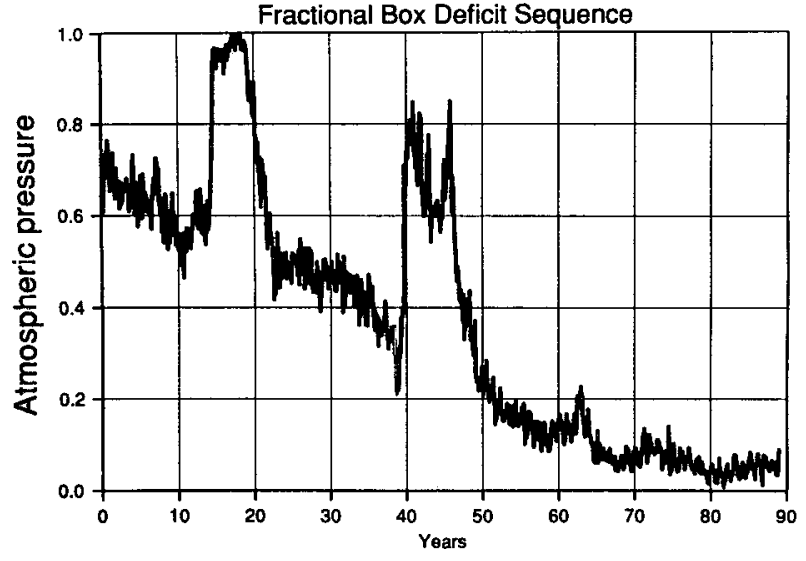

Fig. 1. Typical box deficit sequence for $P_{b}$ for 89 years (19001988 ). Each point represents the fraction of missing data (no data in the box) for the $2^{\circ}$ boxes.

point grid about each box. Curl and div fields were then computed from these plane fits using a constant product of density times drag coefficient, $\rho C_{D}$, equal to $2 \times 10^{-6} \mathrm{~g} \mathrm{~cm}^{-3}$.

\section{Seasonal dependence}

As a prelude to describing the annual and interannual variations of the Sverdrup transports, the climatologically averaged (over 42 years) fields of $P_{b}$, SST, curl, and div are given in Fig. 3 for boreal winter (January) and summer (July) conditions. Henceforth, winter and summer are referenced to the Northern

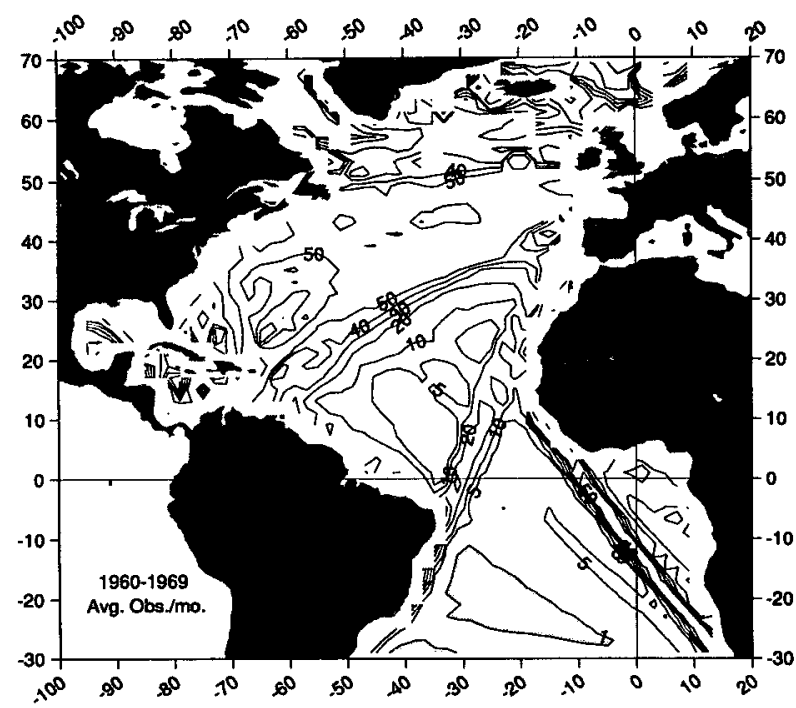

FIG. 2. Typical spatial sampling pattern for the decade 1960-1969. The contours are the average number of observations per month. Shaded area represents less than one observation per month. For Fig. 2 only, contours extend to $70^{\circ} \mathrm{N}$.
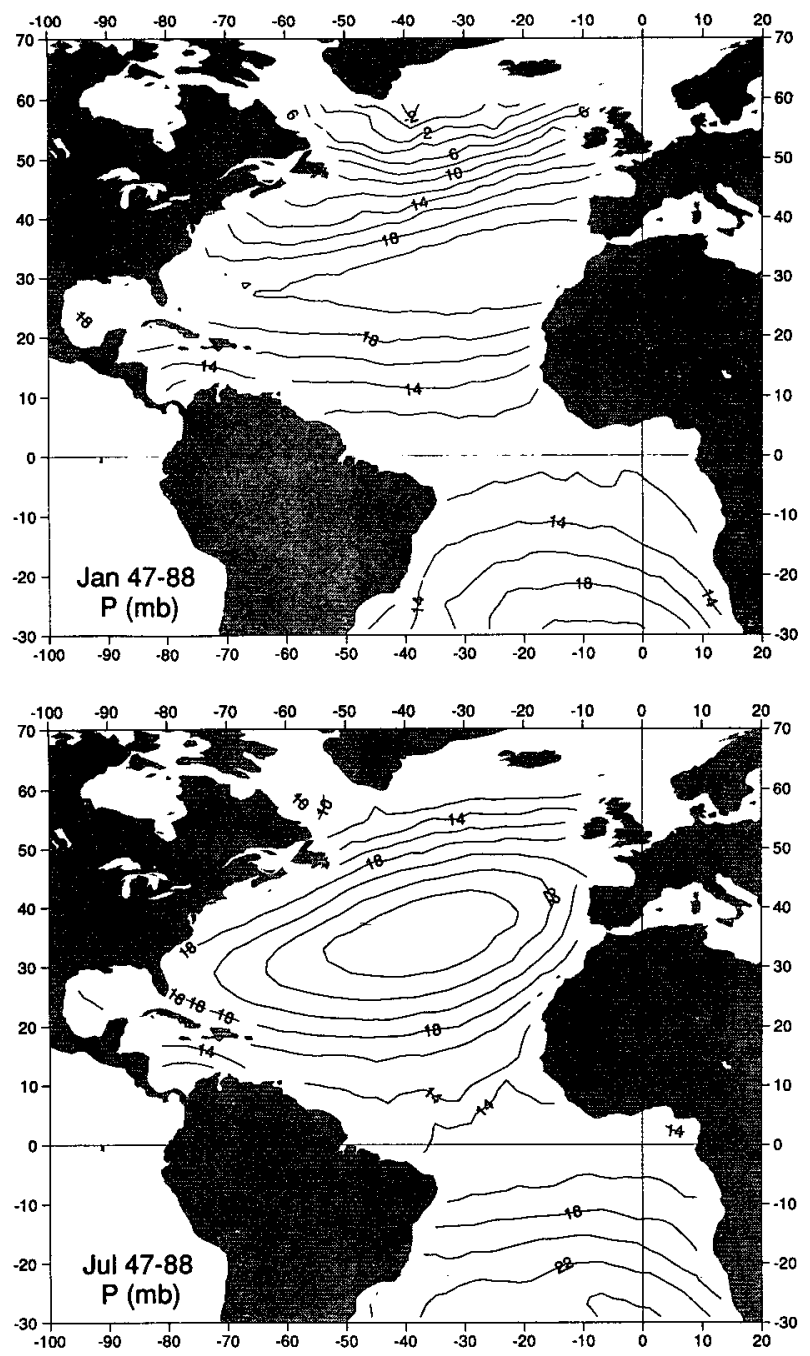

FlG. 3a. Surface atmospheric pressure $\left(P_{b}\right.$ in $\left.\mathrm{mb}-1000\right)$ for (i) 42 Januarys (winter) and (ii) 42 Julys (summer).

Hemisphere. These fields establish the large-scale context within which later inferences will be drawn.

\section{a. Pressure}

Three principal features are manifest in Fig. 3a(i). The edge of the subpolar low above $50^{\circ} \mathrm{N}$, the broad Bermuda-Azores subtropical high pressure ridge and the equatorial low pressure trough. In summer this pattern shifts farther north [Fig. 3a(ii)], compared to winter, and in winter the gradient between the subtropical high and the subpolar low is a maximum. Variations in this pressure difference are referred to as the North Atlantic Oscillation (NAO; Bjerknes 1964). The climatological average value in winter is about 20 $\mathrm{mb}$ and, although not specifically addressed herein, the interannual variations in this index have a range of about $\pm 10 \mathrm{mb}$. In the tropics, the low pressure trough 
also migrates seasonally, consistently overlying a broad region of maximum SST. The intertropical convergence zone (ITCZ) generally coincides with this low pressure trough throughout the year. The position of the ITCZ is also reflected in the curl and div fields that follow.

\section{b. SST}

Contours of SST for winter and summer are given in Figs. 3b(i) and 3b(ii), respectively. Distinctive regions include the western boundary currents, the equator, and the region underlying the tropical low pressure trough. Both seasons show large horizontal gradients associated with the western boundary current above $30^{\circ} \mathrm{N}$. The axis of maximum SST (not drawn) roughly coincides with the low pressure trough (Fig. 3a) throughout the year. In summer, a tonguelike feature of cold water extends along the equator with minimum
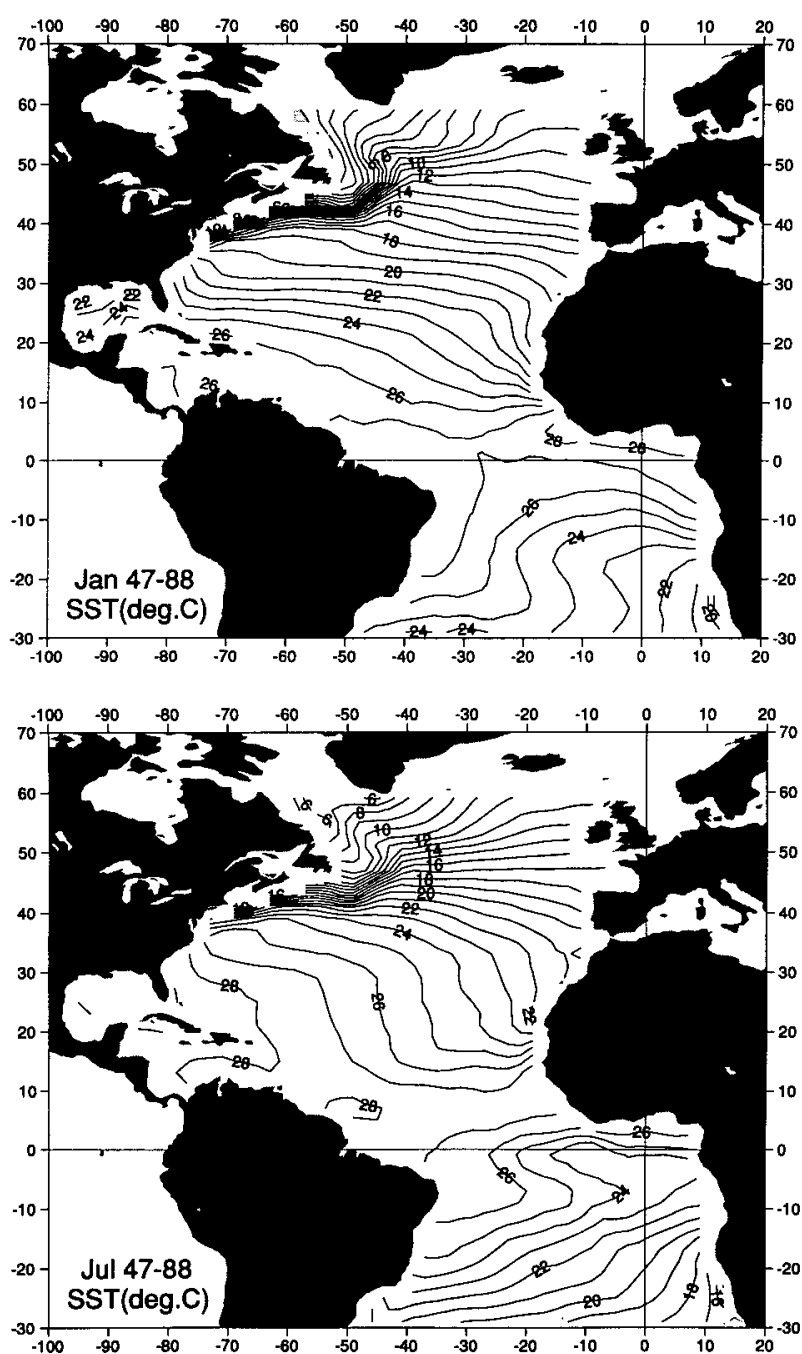

FIG. 3b. SST ( ${ }^{\circ} \mathrm{C}$ ) for (i) 42 Januarys (winter) and (ii) 42 Julys (summer).
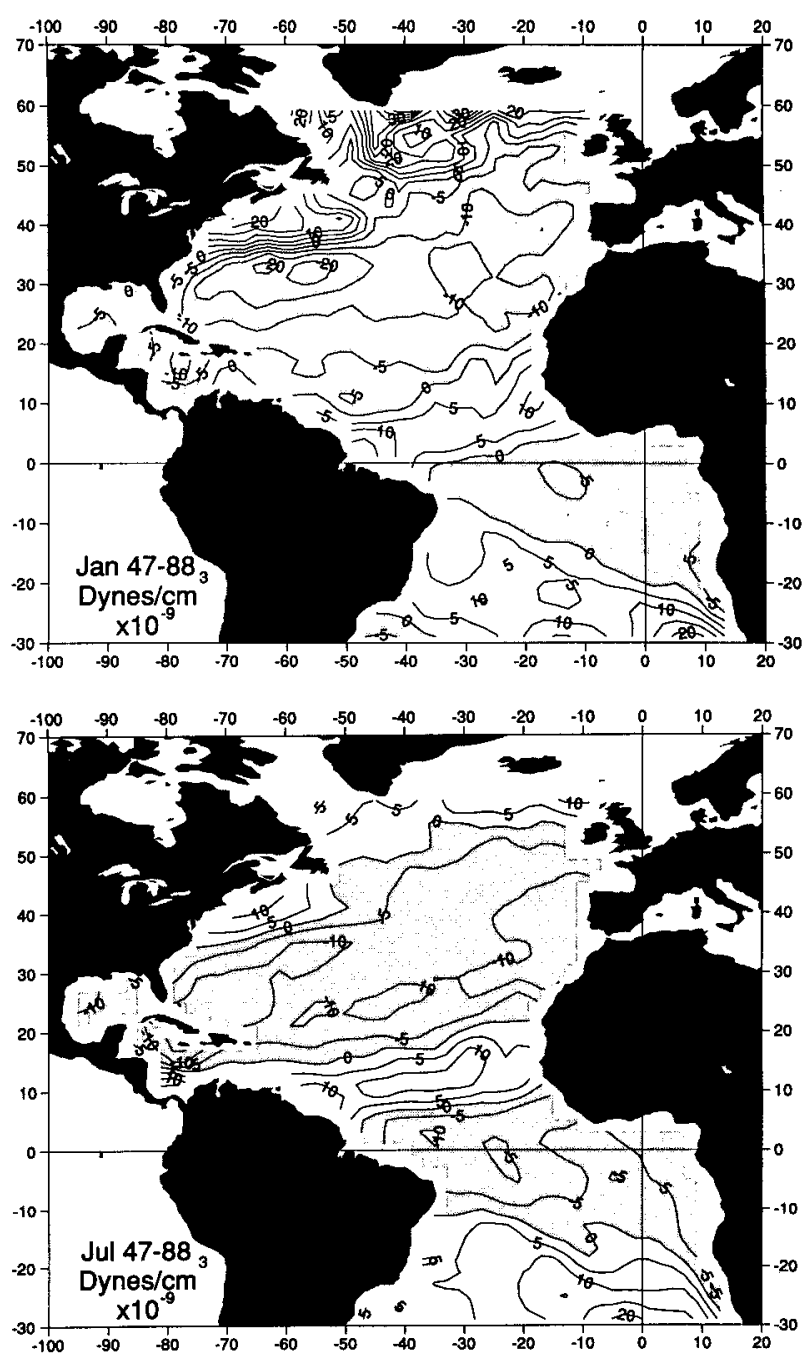

FIG. 3c. Curl (dyn $\mathrm{cm}^{-3} \times 10^{-9}$ ) for (i) 42 Januarys (winter) and (ii) 42 Julys (summer).

SST located at about $10^{\circ} \mathrm{W}$ where the easterly component of wind stress is a minimum. The location and evolution of this feature follows as a response of the equatorial ocean to the seasonal intensification of easterly wind stress (e.g., Weisberg and Tang 1987; Weingartner and Weisberg 1991). The asymmetry about the equator is due to the southerly component of wind stress, which is largest on the eastern side of the basin (e.g., Philander and Pacanowski 1981). The result, on a climatological basis, is a large zonal SST gradient along the equator, which affects the location of the tropical low pressure trough, and hence the ITCZ, by altering the pattern of surface divergence and convergence.

\section{c. Wind-stress curl}

In Figs. 3c(i) and 3c(ii), the double cyclonic (positive) circulation features noted by Leetmaa and 

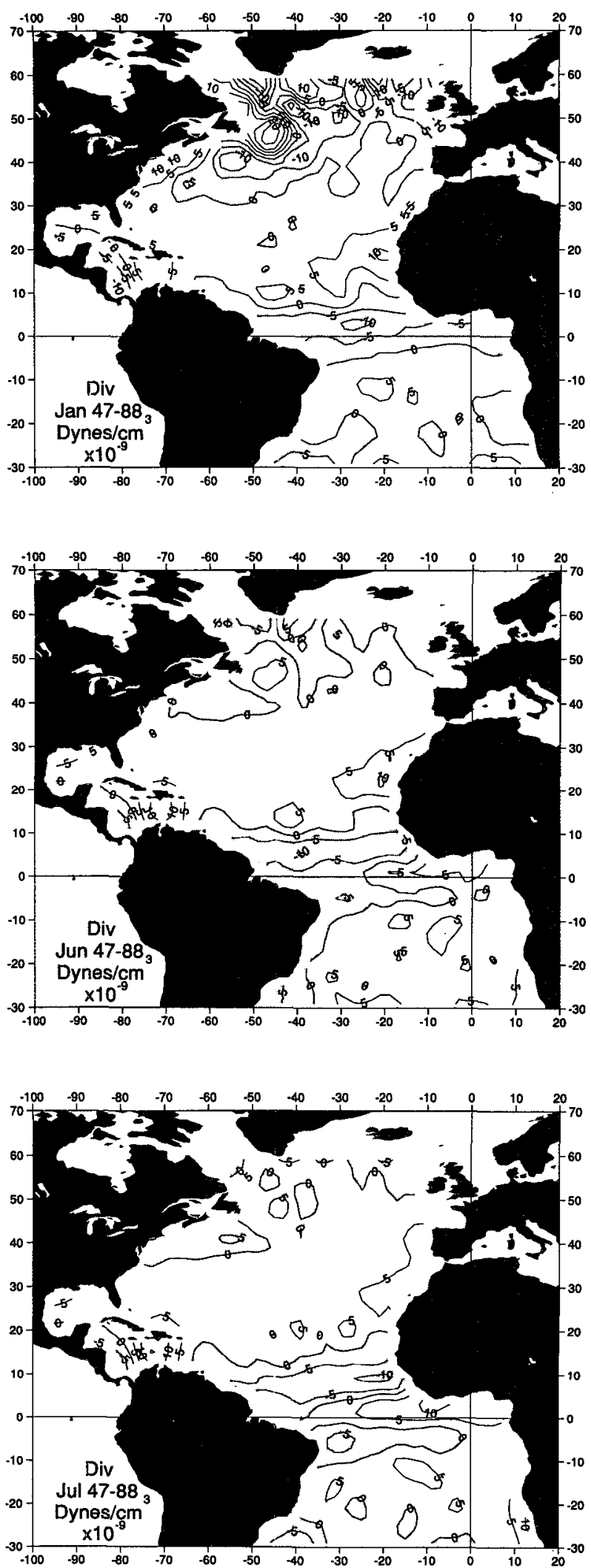

FIG. 3d. Div (dynes $\mathrm{cm}^{-3} \times 10^{-9}$ ) for (i) 42 Januarys (winter), (ii) 42 Junes (summer), and (iii) 42 Julys (summer).
Bunker (1978) are apparent in both seasons off North America near $40^{\circ} \mathrm{N}$ and above $50^{\circ} \mathrm{N}$, with the winter season being much more intense. In the southern part of the Caribbean, as the ITCZ migrates northward, the curl changes sign and this, together with an offshore Ekman transport, results in upwelling off the coast of Venezuela. Separating the large anticyclonic (negative) curl region overlying the Northern Hemisphere subtropical gyre from the negative curl region overlying the equatorial gyre is a region of cyclonic curl just above the equator that extends across the Atlantic Ocean. This cyclonic curl region defines the tropical gyre. Along with the ITCZ, this pattern shifts northward and is more intense in summer than in winter.

\section{d. Wind-stress div}

Both in winter and summer there are only two regions of large negative divergence (Fig. 3d): the northwestern and the tropical regions. The northwestern region shows strong surface convergence (divergence) coincident with cyclonic (anticyclonic) curl in Fig. $3 c(i)$. The tropical region shows maximum convergence coincident with low pressure and high SST (Figs. $3 \mathrm{a}$ and $3 \mathrm{~b}$ ). Between these regions of surface convergence lies the large subtropical region of surface divergence. The seasonal evolution of the surface convergence in the tropics parallels SST, which is largely controlled by ocean dynamics (Weingartner and Weisberg 1991 ). Prior to June, the tropics exhibit a surface convergence across the entire basin. In June, with the appearance of cold water in the eastern half of the basin, the sign of the divergence changes at the equator [Fig. 3d(ii)]. By July, the entire equatorial strip is divergent [Fig. 3d(iii)], separating regions of convergence directly to the north and south. Thus, the developing equatorial cold water tongue splits the div field into two parts. The southern part is smaller than the northern part and begins to break up in August, disappearing in September and October (not shown). The evolution of the div field in the tropics reflects the impact that equatorial ocean dynamics has upon SST and air-sea interaction. Note that these COADS-derived div fields are consistent with those in Hastenrath and Lamb (1977).

\section{Sverdrup transports}

The surface wind-stress components are used to diagnose the implied Sverdrup transports. Assuming that the vertically integrated meridional advection of planetary vorticity is balanced by the wind-stress curl, the vertically integrated Sverdrup mass flux (mass transport per unit width ) vector $V_{S}$ may be expressed as the sum of the Ekman and geostrophic parts:

$$
\mathbb{V}_{\mathrm{S}}=\mathbf{V}_{e}+\mathbf{V}_{g}
$$


where the zonal and meridional components of the Ekman transports are related to the surface wind-stress field $\left.\left(\tau_{x}, \tau_{y}\right)\right|_{0}$ by

$$
\left.\begin{array}{r}
U_{e}=\tau_{y} /\left.f\right|_{0} \\
V_{e}=-\tau_{x} /\left.f\right|_{0}
\end{array}\right\}, \quad[\mathrm{g} /(\mathrm{cm} \mathrm{s})] .
$$

The vertical mass flux at the bottom of the Ekman layer is $\left.\rho w\right|_{B E}=\nabla_{H} \cdot V_{e}\left[\mathrm{~g} /\left(\mathrm{cm}^{2} \mathrm{~s}\right)\right]$, where

$$
\begin{aligned}
\nabla_{H} \cdot \mathbf{V}_{e} & =\frac{\partial U_{e}}{\partial x}+\frac{\partial V_{e}}{\partial y} \\
& =\left.\frac{1}{f} \operatorname{curl} \tau\right|_{0}-\frac{\beta}{f} V_{e}, \\
& =\left.\operatorname{curl}(\tau / f)\right|_{0},
\end{aligned}
$$

and $\beta=\partial f / \partial y$. Vertically integrating the equations of motion with the net water column divergence equal to zero, the meridional Sverdrup transport $\left(V_{\mathrm{S}}\right)$ is obtained from

$$
V_{\mathrm{S}}=\left.\frac{1}{\beta} \operatorname{curl} \tau\right|_{0}
$$

Combining the last two expressions the geostrophic meridional transport $\left(V_{g}\right)$ is related to the Ekman pumping by

$$
\left.\rho w\right|_{B E}=\frac{\beta}{f}\left(V_{\mathrm{S}}-V_{e}\right)=\frac{\beta}{f} V_{g} .
$$

Upward directed pumping generates a convergent poleward $V_{g}\left(V_{g}>0\right.$ in the Northern Hemisphere and conversely) and downward directed pumping generates a divergent equatorward $V_{g}\left(V_{g}<0\right.$ in the Northern Hemisphere and conversely) because the total divergence is zero:

$$
\nabla_{H} \cdot \mathbf{V}_{\mathrm{S}}=\nabla_{H} \cdot \mathbf{V}_{e}+\nabla_{H} \cdot \mathbf{V}_{g}=0
$$

\section{a. Mean annual streamfunction field}

The Sverdrup streamfunction field $\left[\psi\left(V_{\mathrm{S}}\right)\right]$ is obtained by zonally integrating $V_{\mathrm{S}}$ westward from the eastern boundary. This is shown in Fig. 4a for the full 42-year average wind stress. The sign convention is such that $V_{\mathrm{S}}=-\partial \psi / \partial x$ and $U_{S}=\partial \psi / \partial y$. For comparison of results with those of other authors, it is noted that the units of volume transport in $\mathrm{Sv}(1 \mathrm{~Sv} \equiv 1$ $\left.\times 10^{6} \mathrm{~m}^{3} \mathrm{~s}^{-1}\right)$ and mass transport in $\mathrm{g} \mathrm{s}^{-1} \times 10^{12}(\mathrm{al}-$ ternatively $\mathrm{Mt} \mathrm{s}^{-1}$ ) are sometimes used equivalently (owing to water density, this involves an approximate $2.5 \%$ discrepancy.)

The gyres comprising the wind-driven circulation over the analysis domain are evident from the streamfunction in Fig. 4a. From north to south are the lower portion of the cyclonic subpolar gyre, the anticyclonic Northern Hemisphere subtropical gyre, a cyclonic gyre north of the equator referred to as the tropical gyre, a

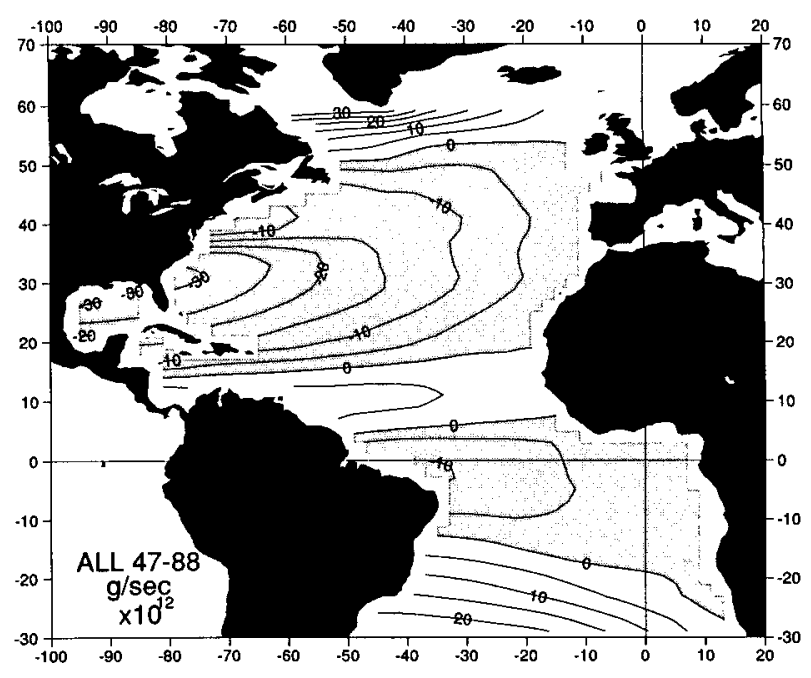

Fig. 4a. Annual average streamfunction field for total Sverdrup transport $\Psi\left(V_{\mathrm{s}}\right) \mathrm{g} \mathrm{s}^{-1} \times 10^{12}\left(\mathrm{Mt} \mathrm{s}^{-1}\right)$ for 504 months.

clockwise gyre straddling the equator referred to as the equatorial gyre, and the upper portion of an anticyclonic Southern Hemisphere subtropical gyre. The North Equatorial Current (NEC) separates the Northern Hemisphere subtropical gyre from the tropical gyre; the North Equatorial Countercurrent (NECC) separates the tropical gyre from the equatorial gyre; and the South Equatorial Current (SEC) separates the equatorial gyre from the Southern Hemisphere subtropical gyre. Three of these gyres have well-documented western boundary current return flows: the Gulf Stream for the Northern Hemisphere subtropical gyre, the North Brazil Current (NBC) for the equatorial gyre, and the Brazil Current (BC) for the Southern Hemisphere subtropical gyre. Closure for the tropical gyre, however, remains undocumented. The cyclonic nature of this gyre suggests a southeastward boundary current (SEBC), but this would be in opposition to a northwestward flowing Guiana Current (GC), as will be discussed.

A composite of the return flows demanded by each of these gyres can be obtained by plotting the zonal integral of $V_{\mathrm{S}}$ or equivalently the values of $\left.\psi\left(V_{\mathrm{S}}\right)\right|_{\mathrm{WB}}$ closest to the western boundary. This is shown in Fig. $4 \mathrm{~b}$. The zonally integrated meridional components for the Sverdrup, Ekman, and geostrophic transports are plotted as a function of latitude. The results are summarized in Table 1, where the average return flow suggested by each of the gyres is indicated for the latitude bands defined by the sign of $\left.\psi\left(V_{\mathrm{S}}\right)\right|_{\mathrm{wB}}$. Additionally, the peak transports are given for the three central gyres.

The latitude dependence of the streamfunction evaluated at the western boundary $\left[\left.\psi\left(V_{\mathrm{S}}\right)\right|_{\mathrm{wB}_{\mathrm{B}}}\right]$ is plotted in Fig. 4c(i) in comparison with the Hellerman and Rosenstein (1983) and Isemer and Hasse (1987) climatologies, HR and IH, respectively (Fig. 8 in Böning et al. (1991). The realization of $\left.\psi\left(V_{\mathrm{S}}\right)\right|_{\mathrm{WB}}$ from the 


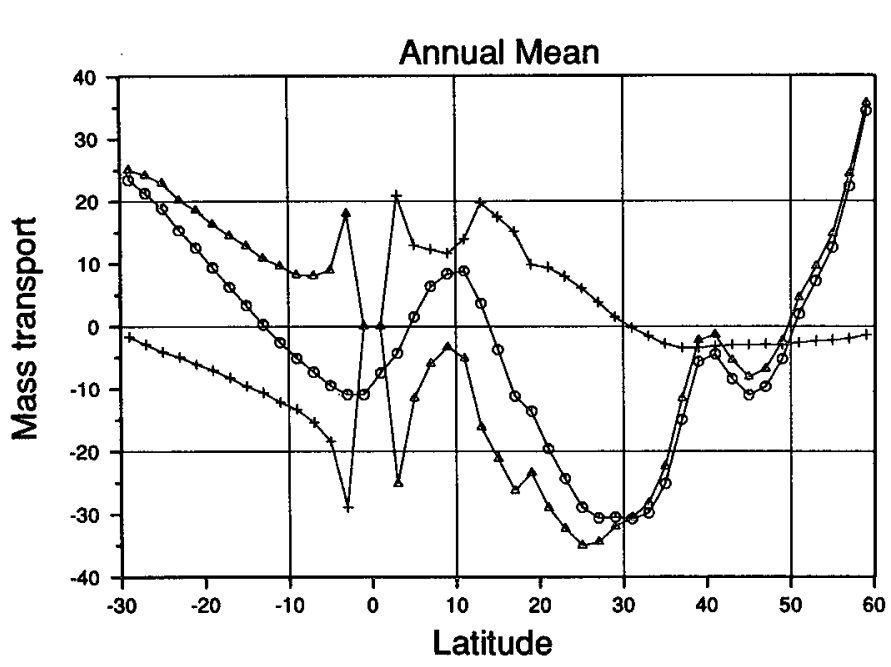

+ Ekman Transport

$\triangle$ Geostrophic Transport

O Total Sv Transport

FIG. 4b. Annual average of meridional Sverdrup transports along the western boundary $\left(\left.\psi\left(V_{\mathrm{S}}\right)\right|_{\mathrm{wB}_{\mathrm{B}}}\right)$ as a function of latitude for the total Sverdrup transport and its components (Ekman and geostrophic), $\mathrm{g} \mathrm{s}^{-1} \times 10^{12}\left(\mathrm{Mt} \mathrm{s}^{-1}\right)$. Each point represents the zonal integral of $V_{\mathrm{S}}, V_{e}$, and $V_{g}$ for 504 months.

COADS is consistent with HR and IH. The zonal integrals for COADS in Fig. 4c(i) also include the region in the Gulf of Mexico and Caribbean, and therefore the transport is overstated between $15^{\circ} \mathrm{N}$ and $27^{\circ} \mathrm{N}$. Upon recomputing values of $\left.\psi\left(V_{S}\right)\right|_{W_{B}}$ (not shown) on a modified grid coinciding with the western boundary of Fig. 7 in Böning et al. (1991), the transport estimates fall between $\mathrm{HR}$ and $\mathrm{IH}$ in this latitude range.

Because the streamfunction is computed from derivatives of the surface wind stress, the zonally averaged wind-stress components are also compared at selected latitudes in Fig. 4c(ii) (from Fig. 5 of Böning et al. 1991). The largest discrepancy for the zonal component appears at $14^{\circ} \mathrm{N}$. Here COADS underestimates HR in the summer, but at other latitudes COADS is consistent with HR. For the meridional component, COADS generally falls between $\mathrm{HR}$ and $\mathrm{IH}$.

TABLE 1. Average $\left.\psi\left(V_{S}\right)\right|_{W_{B}}$ between indicated latitudes for 42 years (504 months). Return flows are of opposite sign.

\begin{tabular}{cccc}
\hline \hline $\begin{array}{c}\left.\bar{\psi}\left(V_{\mathrm{S}}\right)\right|_{\mathrm{wB}} \\
\left(\mathrm{g} \mathrm{s}^{-1} \times 10^{12}\right) \\
\left.(\text { or Mt s})^{-1}\right)\end{array}$ & Latitude band & $\begin{array}{c}\text { Relative peak } \\
\text { transport } \\
\left(\mathrm{g} \mathrm{s}^{-1} \times 10^{12}\right) \\
\left(\mathrm{or} \mathrm{Mt} \mathrm{s}^{-1}\right)\end{array}$ & $\begin{array}{c}{ }^{*} \text { Latitude of } \\
\text { relative peak } \\
\text { transport }\end{array}$ \\
\hline 13.8 & $29^{\circ} \mathrm{S}-13^{\circ} \mathrm{S}$ & - & - \\
-7.2 & $11^{\circ} \mathrm{S}-3^{\circ} \mathrm{N}$ & -11 & $3^{\circ} \mathrm{S}$ \\
5.7 & $5^{\circ} \mathrm{N}-13^{\circ} \mathrm{N}$ & 9 & $11^{\circ} \mathrm{N}$ \\
-17.1 & $15^{\circ} \mathrm{N}-49^{\circ} \mathrm{N}$ & -31 & $31^{\circ} \mathrm{N}$ \\
-20.7 & $15^{\circ} \mathrm{N}-39^{\circ} \mathrm{N}$ & - & - \\
15.7 & $51^{\circ} \mathrm{N}-59^{\circ} \mathrm{N}$ & - & - \\
\hline
\end{tabular}

* Note that for the subtropical gyre relative peak transport between 30 and $31 \mathrm{Mt} \mathrm{s}^{-1}$ forms a broad peak over a range of latitudes between $29^{\circ} \mathrm{N}$ and $33^{\circ} \mathrm{N}$.
The implications for numerical models run with different climatological winds are discussed in Böning et al. (1991). For the purposes of this report, the small differences between COADS and HR and IH are inconsequential.

\section{b. Seasonal dependence}

The meridional Ekman transports $\left(V_{e}\right)$ for winter and summer are plotted in Figs. 5a(i) and 5a(ii). In both seasons, the largest transports occur near the equator in the western half of the basin. In winter, the meridional Ekman transports are uniformly convergent all the way to the center of the Northern Hemisphere subtropical gyre. In summer, the meridional Ekman transports are tightly confined to the equator; they are convergent between the equator and the center of the equatorial gyre (coinciding with the NECC dynamic height ridge) and divergent between the center of the equatorial gyre and the center of the tropical gyre (coinciding with the NEC dynamic height trough). These differences between the meridional Ekman transports in winter and summer are reflected in the seasonal differences in intensity of the tropical and equatorial gyres. An additional feature of interest is the region of developing southward transport associated with the veering of winds toward the West African coast during summer monsoon conditions.

The vertical mass flux at the base of the Ekman layer $\left(\left.\rho w\right|_{\mathrm{BE}}=W_{e}\right)$, the meridional geostrophic transport $\left(V_{g}\right)$, and the total meridional Sverdrup transport $\left(V_{\mathrm{S}}\right)$ are plotted for winter and summer in Figs. $5 b(\mathrm{i})$ and $5 \mathrm{~b}$ (ii), $5 \mathrm{c}$ (i) and $5 \mathrm{c}$ (ii), and $5 \mathrm{~d}$ (i) and $5 \mathrm{~d}$ (ii), respectively. Owing to increasing baroclinic adjustment times with latitude, these Sverdrup circulation derived fields, 

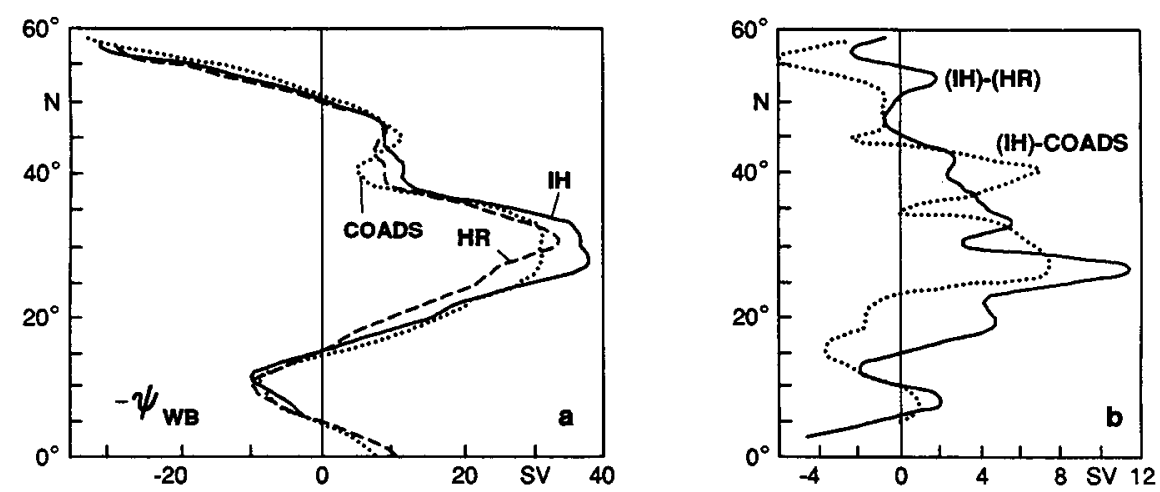

FIG. 4c. (i). Comparison of annual average of meridional Sverdrup transport along the western boundary $\left(-\left.\psi\left(V_{\mathrm{S}}\right)\right|_{\mathrm{WB}}\right)$ from COADS (dotted) as a function of latitude with those from HR (dashed) and IH (solid) climatologies. (a) Reproduced from Böning et al. (1991) from their Fig. 8. Units are in Sverdrups $\left(1 \mathrm{~Sv} \equiv 1 \times 10^{6} \mathrm{~m}^{3} \mathrm{~s}^{-1}\right)$. Note sign convention of streamfunction is the negative of that used herein; (b) difference between IH and COADS (dotted) and IH and HR (solid).
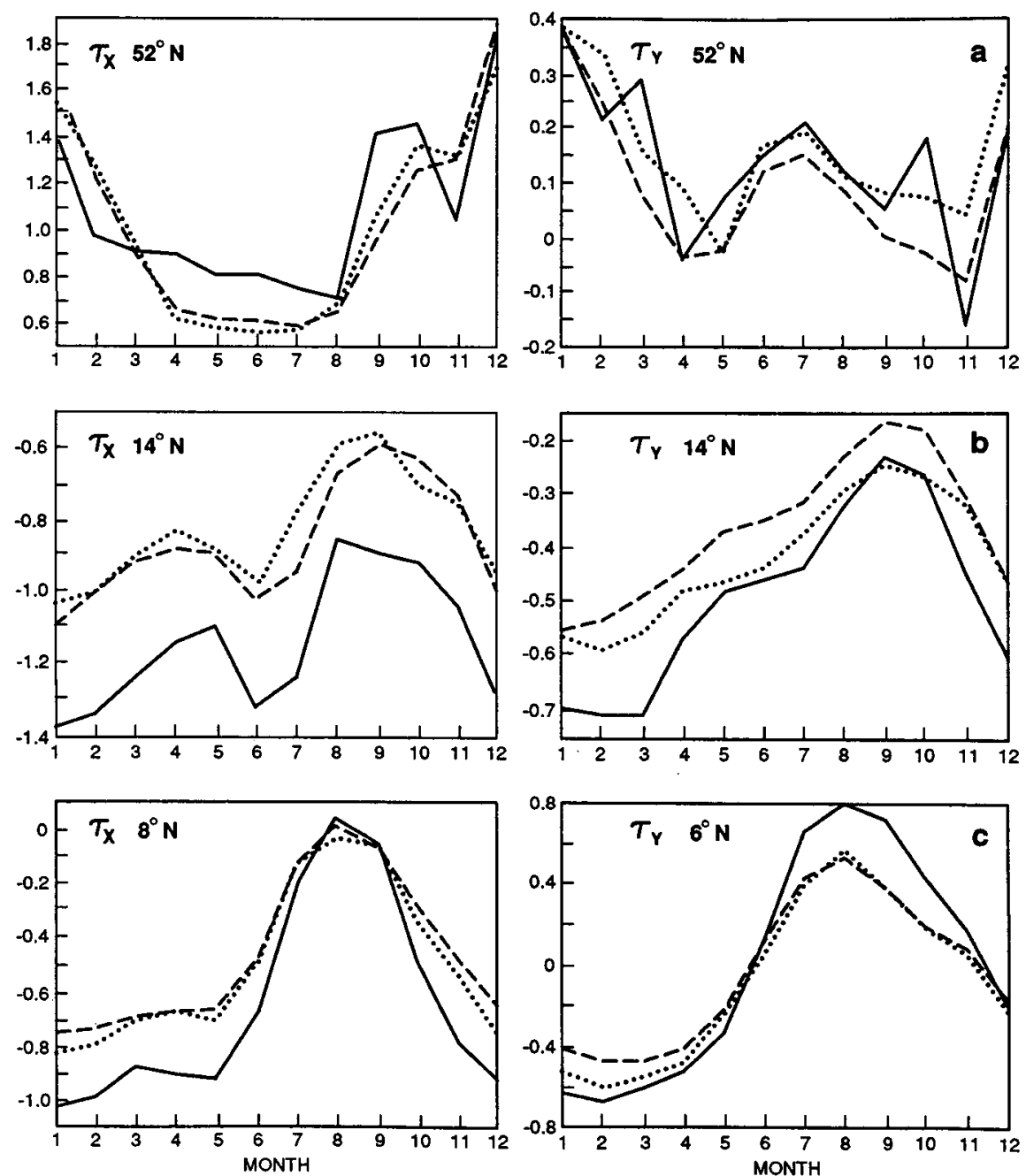

FIG. 4c. (ii). Comparison of time dependence of the zonally averaged wind-stress components from COADS (dotted) at selected latitudes [(a) $52^{\circ} \mathrm{N}$, (b) $14^{\circ} \mathrm{N}$, (c) $8^{\circ} \mathrm{N}$ and $6^{\circ} \mathrm{N}$ ] with those from HR (dashed) and IH (solid) climatologies. Reproduced from Böning et al. (1991) from their Fig. 5. Units are in dynes $\mathrm{cm}^{2}$. 

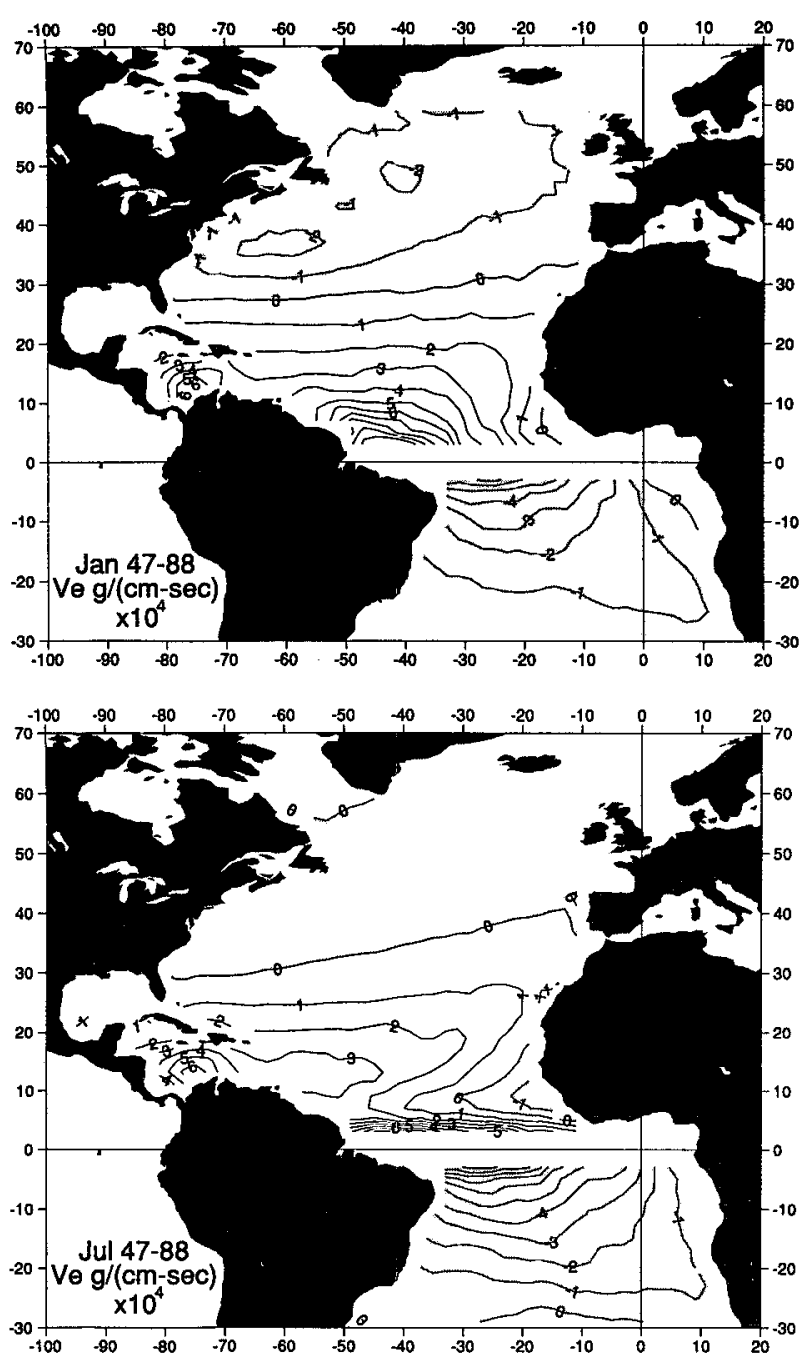

FIG. 5a. Meridional Ekman transport $\left(V_{e}\right) \mathrm{g}(\mathrm{cm} \mathrm{s})^{-1} \times 10^{4}$ for (i) 42 Januarys (winter) and (ii) 42 Julys (summer).

$V_{g}$ and $V_{\mathrm{S}}$, give indications only of tendencies (e.g., Böning et al. 1991), especially outside of the tropics. Positive contours denote upward flow for $W_{e}$ and poleward flow for $V_{g}$ and $V_{\mathrm{S}}$, respectively. Within the two cyclonic features near the coast in the northwestern Atlantic Ocean region (Fig. 3c), $V_{e}$ is equatorward owing to westerly wind stress, while $W_{e}$ and $V_{g}$ and $V_{\mathrm{S}}$ are upward and poleward, respectively, with largest magnitudes in winter. The return flow of the cyclonic gyre closest to North America is consistent with a southwestward flow along the continental shelf (Leetmaa and Bunker 1978; Csanady and Hamilton 1988).

In the subtropical gyre, $W_{e}, V_{g}$, and $V_{\mathrm{S}}$ are downward and equatorward, respectively, with the western boundary current return flow being the Florida Current and the Gulf Stream system. These features are evident in the streamfunction field $\psi\left(V_{\mathrm{S}}\right)$ in Figs. 5e(i) and $5 \mathrm{e}$ (ii) for winter and summer, respectively.
Just above the equator in the tropical (cyclonic) gyre [Figs. 5d(i)-(ii) and 5e(i)-(ii)], positive contours of $W_{e}$ (upward) and $V_{g}$ (poleward) spread across the Atlantic from northwestern Africa [Figs. 5b(i)-(ii) and $5 c(i)-(i i)]$, going partially across the basin in winter and completely across in summer. Despite the curl being positive all year in this region (suggestive of positive $W_{e}$ in wintertime), $W_{e}$ is negative in the central and western portions of the basin. This occurs because $V_{e}=-\tau^{x} / f$ is stronger, positive, and not as confined to the equator in winter. Thus, during winter, the $(\beta /$ f) $V_{e}$ term overwhelms the $\left.(1 / f) \operatorname{curl} \tau\right|_{0}$ term in determining $W_{e}$. The seasonal variation in $W_{e}$ sets up the system of dynamic topography ridges and troughs (e.g., Garzoli and Katz 1983; Merle and Arnault 1985) that delimit the tropical and equatorial gyres and balance the zonally oriented NEC, NECC, and SEC. In summertime, these gyres are most developed with the
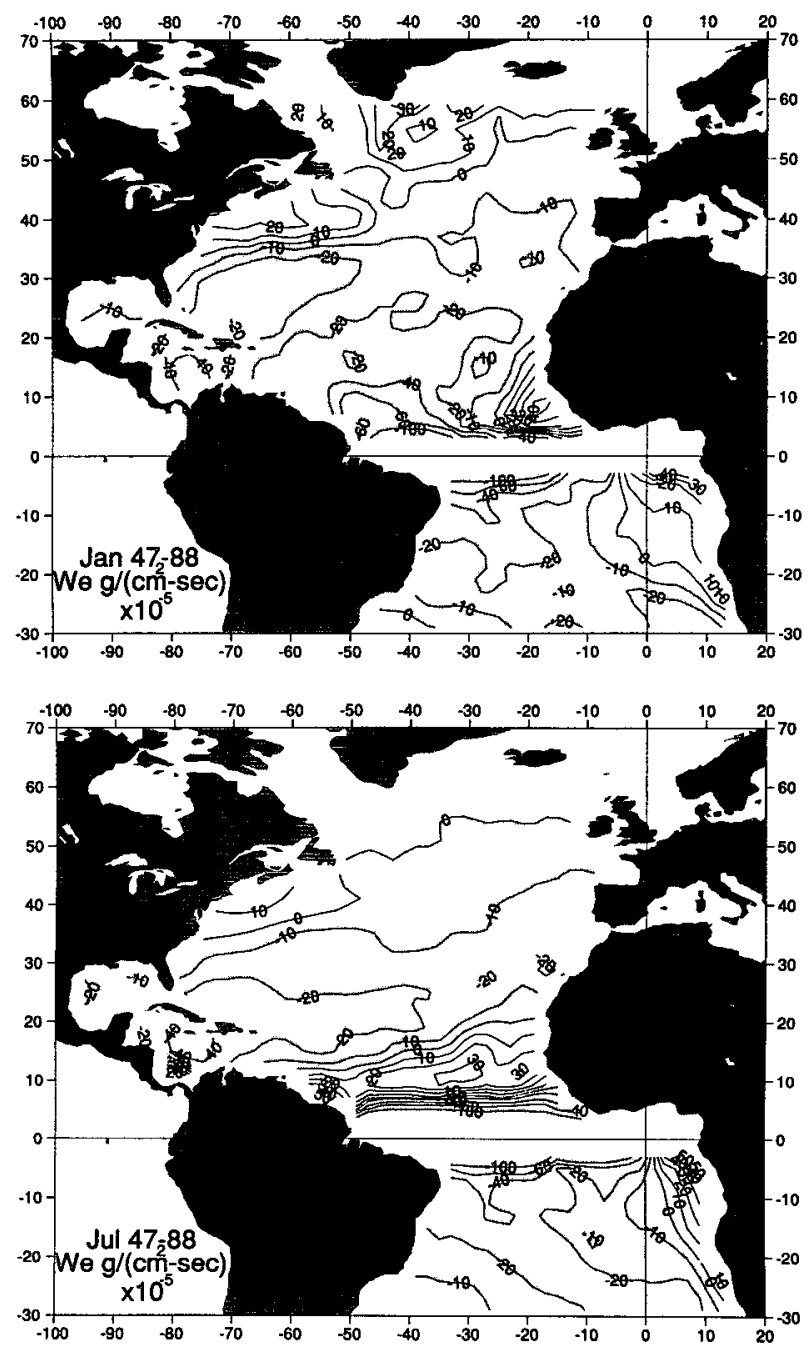

FIG. 5b. Vertical Ekman mass flux $\left(\left.\rho w\right|_{B E}=W_{e}\right) \mathrm{g}\left(\mathrm{cm}^{2} \mathrm{~s}\right)^{-1}$ $\times 10^{-5}$ for (i) 42 Januarys (winter) and (ii) 42 Julys (summer). 

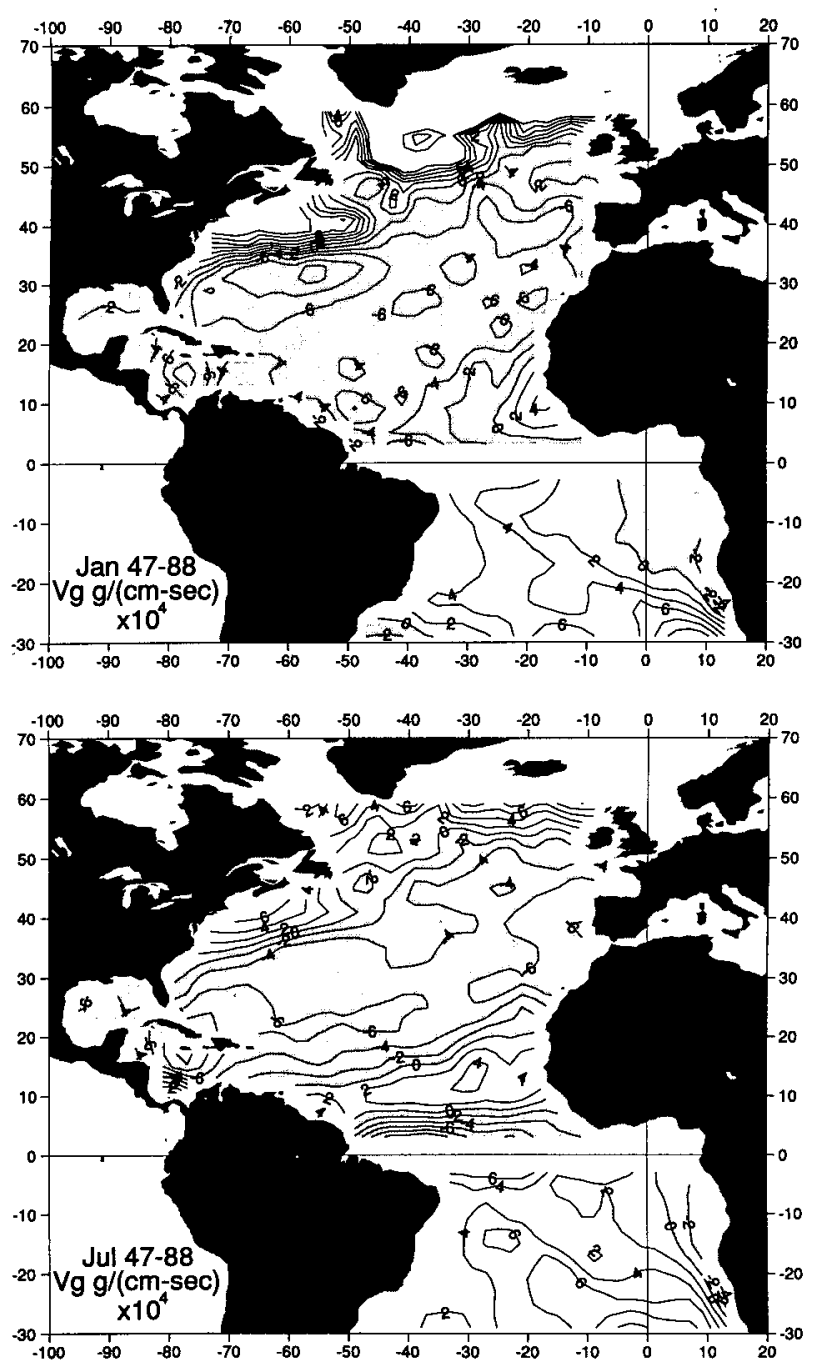

FIG. 5c. Meridional geostrophic transport $\left(V_{g}\right) \mathrm{g}(\mathrm{cm} \mathrm{s})^{-1} \times 10^{4}$ for (i) 42 Januarys (winter) and (ii) 42 Julys (summer).

NEC trough acting as a dynamical barrier to water exchange between the tropical gyre and the Northern Hemisphere subtropical gyre. The cyclonic polarity of the tropical gyre provides the conundrum alluded to earlier. It suggests the existence of a SEBC in the same region where a northwestward flowing $\mathrm{GC}$ is often referred to. Whether or not the GC is a persistent feature of the western tropical Atlantic circulation remains a question, but it is noted here that such a current is inconsistent with the Sverdrup interior circulation, either in winter or in summer. Just to the south of the implied SEBC is the northwestward flowing NBC, which provides western-boundary-current closure for the clockwise equatorial gyre. The NBC is strongest in summer, when the equatorial gyre is strongest and positioned farthest to the north. It retroflects near $5^{\circ} \mathrm{N}$ and flows into the NECC. In summer, the streamfunction [Fig. $5 \mathrm{e}$ (ii)] also shows an indication of a
South Equatorial Countercurrent (SECC), as reported by Molinari (1983) and by Hisard et al. (1986). A similar structure is manifest in the streamfunction field of Hellerman and Rosenstein (1983). The COADS shows this feature from June through October.

On the eastern side of the basin in the Southern Hemisphere while $W_{e}$ is positive (upwelling) off the African coast, $V_{\mathrm{S}}, V_{g}$, and $V_{e}$ are all directed southward. This implies that horizontal advection is not important in maintaining cold equatorial SST.

Near the equator, $V_{\mathrm{S}}$ is southward across the entire basin, while $V_{g}$ is convergent and $V_{e}$ is divergent about the equator. From the standpoint of the Sverdrup circulation, this implies that it is only at the western boundary that the net Sverdrup circulation can transport water from the Southern into the Northern Hemisphere, as required to balance the overturning mode of circulation for the Atlantic Ocean.

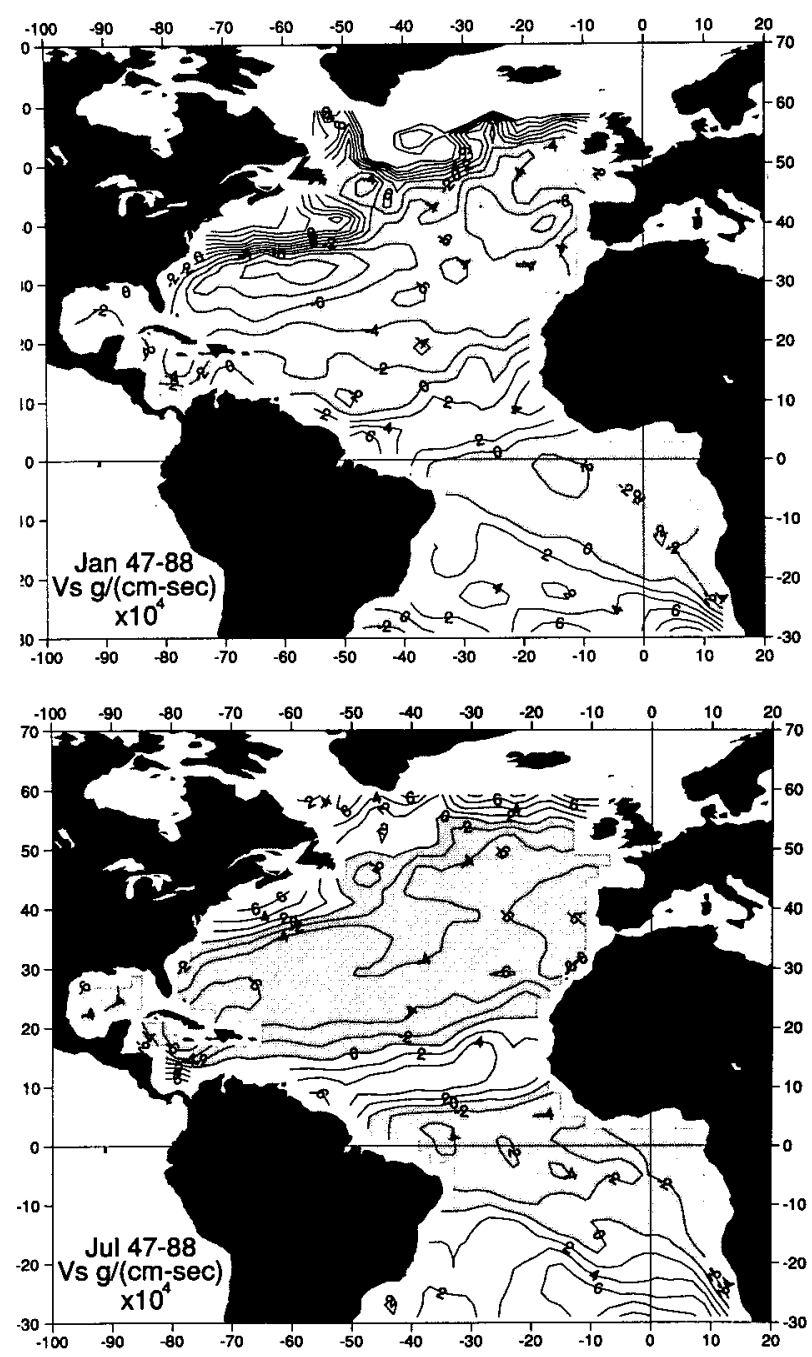

FIG. 5d. Meridional total Sverdrup transport $\left(V_{S}\right) \mathrm{g}(\mathrm{cm} \mathrm{s})^{-1}$ $\times 10^{4}$ for (i) 42 Januarys (winter) and (ii) 42 Julys (summer). 

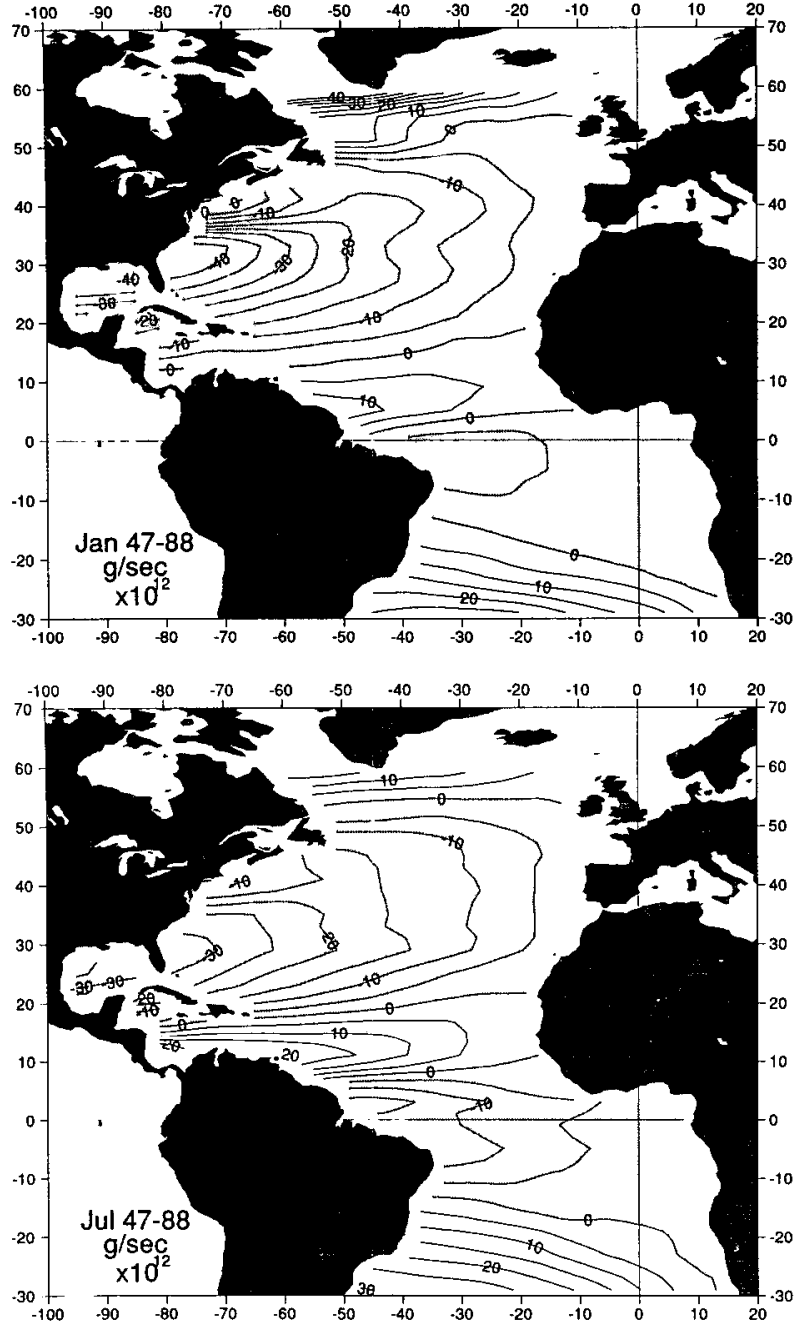

FIG. 5e. Streamfunction field for total Sverdrup transport $\psi\left(V_{\mathrm{S}}\right)$ $\mathrm{g} \mathrm{s}^{-1} \times 10^{12}\left(\mathrm{Mt} \mathrm{s}^{-1}\right)$ for (i) 42 Januarys (winter) and (ii) 42 Julys (summer).

The seasonal dependence of the western boundary current return flows can be deduced by computing the zonal integrals of the constituent Sverdrup transports by month and contouring the results as a function of time and latitude. This has been done for $V_{e}, V_{g}$, and $V_{\mathrm{S}}$, respectively, in Figs. 6a-c. Again, these Sverdrup fields represent tendencies only. Contours of the zonal integral of $V_{e}$ (Fig. 6a) are in good agreement with those from Levitus (1988). In Table 2, the zonal integrals have been organized for the four seasons defined here for this purpose as winter (December-JanuaryFebruary), spring (March-April-May), summer (June-July-August), and fall (September-OctoberNovember), providing a seasonal breakdown of Table 1. In addition to the average $\left.\psi\left(V_{\mathrm{S}}\right)\right|_{\mathrm{wB}_{\mathrm{B}}}$ between the latitudes of each gyre, the peak transport and its latitude are also indicated. The largest seasonal variability for the zonal integral of $V_{e}$ is within $10^{\circ}$ of the equator, and therefore the zonal integral of $V_{g}$ (Fig. 6b) differs significantly from $\left.\psi\left(V_{\mathrm{S}}\right)\right|_{\mathrm{WB}_{\mathrm{B}}}$ (Fig. $6 \mathrm{c}$ ) in its seasonal dependence within this near-equator region. In Fig. 6c, the subtropical gyre seasonal amplitude varies by roughly $20 \mathrm{Mt} \mathrm{s}^{-1}$. This amplitude variation is consistent with the model result of Anderson and Corry (1985).

With regard to the seasonal dependence of the relative peak transport $\left.\psi\left(V_{\mathrm{S}}\right)\right|_{\mathrm{wB}}$ for the central three gyres in Table 2 and in Fig. $6 \mathrm{c}$, the equatorial gyre has a maximum transport in August and September of about $-15 \mathrm{Mt} \mathrm{s}^{-1}$ and a minimum in January and February of about $-8 \mathrm{Mt} \mathrm{s}^{-1}$. The range of latitudes is between about $3^{\circ} \mathrm{S}$ and $3^{\circ} \mathrm{N}$. For the tropical gyre, there is a maximum in July and August with a broad range of minimum values from November to April. The range of latitudes is between about $5^{\circ} \mathrm{N}$ to $11^{\circ} \mathrm{N}$ with a transport that changes from a minimum of $10 \mathrm{Mt} \mathrm{s}^{-1}$ in the spring to a maximum of $22 \mathrm{Mt} \mathrm{s}^{-1}$ in the summer. Even during the winter season, when a continuous western boundary current connecting the tropics with the Caribbean (the GC) would be most likely, Fig. 6c and Table 2 suggest a substantial oppositely directed flow. In the subtropical gyre, there is a double maximum from January to March (about $-42 \mathrm{Mt} \mathrm{s}^{-1}$ ) and again in July (about $-35 \mathrm{Mt} \mathrm{s}^{-1}$ ) and a minimum in September and October (about $-21 \mathrm{Mt} \mathrm{s}^{-1}$ ) over a range of latitudes from $27^{\circ} \mathrm{N}$ to $33^{\circ} \mathrm{N}$. The relative minimum peak transport near about $40^{\circ} \mathrm{N}$ (Fig. $4 \mathrm{~b}$ ) fluctuates over a range that changes sign from $12 \mathrm{Mt} \mathrm{s}^{-1}$ in March to $-16 \mathrm{Mt} \mathrm{s}^{-1}$ in October and is associated with the cyclonic feature [Figs. 3c(i) and 3c(ii)] in the northwestern Atlantic Ocean.

\section{Annual and interannual signals}

Annual and interannual variability of the curl fields is addressed by computing the spatial distribution of variance in different frequency bands, comparing the spatial distribution of curl over six different pentads between 1955 and 1984, and calculating time series of $\left.\psi\left(V_{\mathrm{S}}\right)\right|_{\mathrm{WB}}$.

\section{a. Variance fields}

Regions of active annual and interannual wind-stress curl variations are described by Figs. 7a-d. The curl field data were rearranged into 42-year long time series, one for each $2^{\circ} \times 2^{\circ}$ grid box, exclusive of the boundaries where curl could not be computed. Three frequency bands are examined, as defined in Table 3. These are AN, IAN, and LP, in abbreviation for annual, interannual, and low pass, respectively, with LP including all frequencies through semiannual.

Each time series was Fourier transformed, and two normalized variance fields (fractional variance and variance/max ) were computed. The fractional variance (FVR) fields in Figs. 7a and 7c for the AN and the 

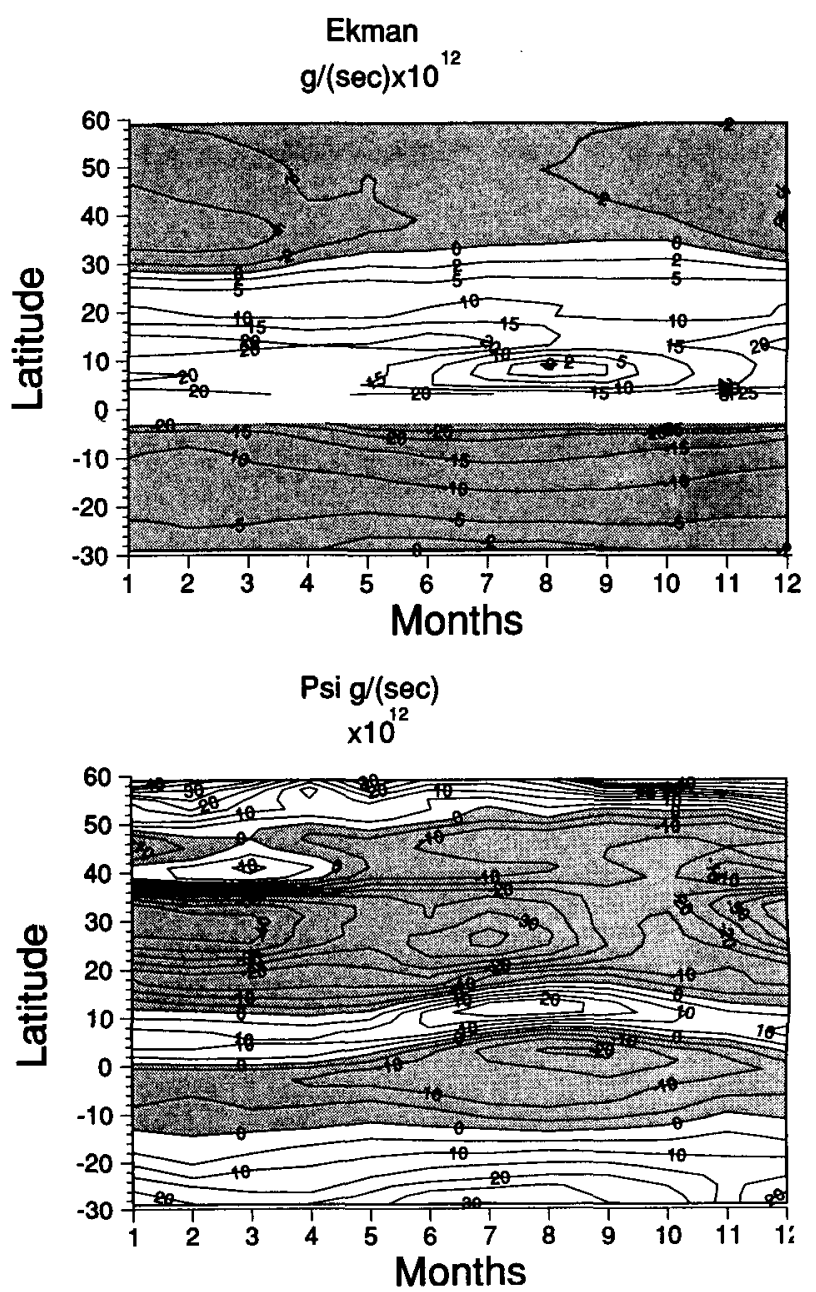

IAN bands were computed by dividing the variance of these bands by the total local LP variance. A semiannual cutoff was chosen to reduce aliasing by monthly sampling. The variance/max (VRM) fields in Figs. $7 \mathrm{~b}$ and $7 \mathrm{~d}$ were obtained by dividing the variance of the $\mathrm{AN}$ and IAN bands by the maximum variance observed over the analysis domain for each of these two bands. Thus, the FVR fields represent relative magnitude of the AN and IAN bands compared to LP, irrespective of absolute variance level. The VRM fields provide the variance level information, so between FVR and VRM, annually and interannually active regions can be identified.

\section{1) AN BAND}

Four principal regions of active $\mathrm{AN}$ band variance are identified in Fig. $7 \mathrm{a}$ by the 0.3 contour $(30 \%$ of the curl field variance residing in the AN band). The subtropical gyre, for the 0.3 contour, splits into two parts, one near $40^{\circ} \mathrm{N}$ extending eastward to about $45^{\circ} \mathrm{W}$ and a larger region near $30^{\circ} \mathrm{N}$ extending to about $50^{\circ} \mathrm{W}$.

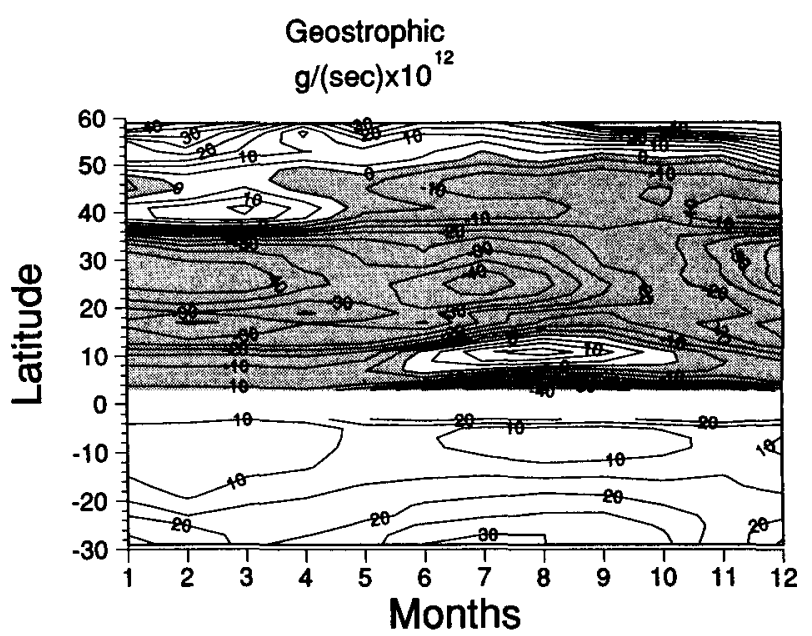

FIG. 6. Contours of zonal integral of meridional (a) Ekman $\left(V_{e}\right)$, (b) geostrophic $\left(V_{g}\right)$, and $(\mathrm{c})$ total Sverdrup $\left(V_{\mathrm{S}}\right)$ transport $\mathrm{g} \mathrm{s}^{-1} \times 10^{12}$ $\left(\mathrm{Mt} \mathrm{s}^{-1}\right.$ ) by month for 42 months.

In the tropics, just above the equator, the ridge along the $0.8-0.7$ contours conforms approximately with the mean position of the ITCZ, which extends from about $1^{\circ} \mathrm{N}-2^{\circ} \mathrm{N}$ in the western Atlantic to about $6^{\circ} \mathrm{N}-7^{\circ} \mathrm{N}$ in the eastern Atlantic. Just above this region, the FVR field exceeds 0.5 in two places, one in the western Atlantic near $10^{\circ} \mathrm{N}$ and one in the eastern Atlantic near $13^{\circ} \mathrm{N}$. The former is associated with the change in sign of the curl in winter when the ITCZ is near its southernmost position.

The VRM field for the AN band, given in Fig. 7b, shows that the maximum AN band variance is above $50^{\circ} \mathrm{N}$ just south of Greenland where the variance increases dramatically northward all across the Atlantic. Outside of this subpolar gyre region only four other regions, two in the subtropics and two in the tropics, stand out, as outlined by the 0.10 contour. Within these other regions the AN variance is an order of magnitude smaller than that in the subpolar region. Thus, large areas of the subtropical Northern and Southern Hemisphere gyres are influenced very little by annual windstress curl variations relative to the tropics and the 
northwestern and subpolar regions. Implicit in these results are the regions where the AN variance is less important than the IAN variance, and thus the baroclinic adjustment time scale becomes less of a factor when integrating the steady-state Sverdrup fields for selected areas of the Atlantic.

\section{2) IAN BAND}

Inspection of the FVR field in Fig. 7c reveals two large regions exceeding the 0.3 level. In the North Atlantic, while noisy, this contour outlines a plateau encompassing the central and eastern Atlantic above $20^{\circ} \mathrm{N}$ and across the whole ocean above $35^{\circ} \mathrm{N}$. Almost the entire South Atlantic exceeds the 0.3 level. Thus, interannual variability exceeds annual variability by a factor of 2 for most of the South Atlantic and by a factor of 1.5 or more for the North Atlantic outside of

TABLE 2. Average seasonal dependence of $\left.\psi\left(V_{\mathrm{S}}\right)\right|_{\mathrm{WB}}$ between indicated latitudes for 42 years. Return flows are of opposite sign. Seasons are winter (Dec-Jan-Feb), spring (Mar-Apr-May), summer (Jun-Jul-Aug), and fall (Sep-Oct-Nov).

\begin{tabular}{|c|c|c|c|}
\hline $\begin{array}{c}\left.\bar{\psi}\left(V_{\mathrm{s}}\right)\right|_{\mathrm{WB}} \\
\left(\mathrm{g} \mathrm{s}^{-1} \times 10^{12}\right) \\
\left(\text { or } \mathrm{Mt} \mathrm{s}^{-1}\right)\end{array}$ & Latitude band & $\begin{array}{l}\text { Relative peak } \\
\text { transport } \\
\left(\mathrm{g} \mathrm{s}^{-1} \times 10^{12}\right) \\
\left(\text { or } \mathrm{Mt} \mathrm{s}^{-1}\right)\end{array}$ & $\begin{array}{l}\text { Latitude of } \\
\text { relative peak } \\
\text { transport }\end{array}$ \\
\hline
\end{tabular}

\section{Winter}

$\begin{array}{rccc}12.0 & 29^{\circ} \mathrm{S}-15^{\circ} \mathrm{S} & - & - \\ -5.4 & 11^{\circ} \mathrm{S}-1^{\circ} \mathrm{S} & -8 & 3^{\circ} \mathrm{S} \\ 7.8 & 3^{\circ} \mathrm{N}-11^{\circ} \mathrm{N} & 11 & 5^{\circ} \mathrm{N} \\ -20.1 & 13^{\circ} \mathrm{N}-47^{\circ} \mathrm{N} & -42 & 31^{\circ} \mathrm{N} \\ -23.8 & 13^{\circ} \mathrm{N}-39^{\circ} \mathrm{N} & - & - \\ 25.2 & 51^{\circ} \mathrm{N}-59^{\circ} \mathrm{N} & - & -\end{array}$

\section{6}

$-6.7$

7.8

$-16.0$

$-23.6$

12.9

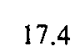

$-11.2$

11.6

$-19.3$

$-22.9$

10.6

12.8

$-9.6$

6.3

$-14.3$

$-14.9$

22.0
Spring

$$
\begin{aligned}
& 29^{\circ} \mathrm{S}-15^{\circ} \mathrm{S} \\
& 11^{\circ} \mathrm{S}-1^{\circ} \mathrm{S} \\
& 1^{\circ} \mathrm{N}-9^{\circ} \mathrm{N} \\
& 13^{\circ} \mathrm{N}-49^{\circ} \mathrm{N} \\
& 13^{\circ} \mathrm{N}-37^{\circ} \mathrm{N} \\
& 51^{\circ} \mathrm{N}-59^{\circ} \mathrm{N}
\end{aligned}
$$

$$
\begin{array}{r}
-10 \\
10 \\
-34 \\
- \\
-
\end{array}
$$

\section{$3^{\circ} \mathrm{S}$}

$5^{\circ} \mathrm{N}$

$30^{\circ} \mathrm{N}$

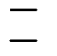

Summer

$\begin{array}{rrc}29^{\circ} \mathrm{S}-15^{\circ} \mathrm{S} & - & - \\ 11^{\circ} \mathrm{S}-5^{\circ} \mathrm{N} & -15 & 3^{\circ} \mathrm{N} \\ 7^{\circ} \mathrm{N}-15^{\circ} \mathrm{N} & 22 & 11^{\circ} \mathrm{N} \\ 17^{\circ} \mathrm{N}-49^{\circ} \mathrm{N} & -33 & 27^{\circ} \mathrm{N} \\ 17^{\circ} \mathrm{N}-39^{\circ} \mathrm{N} & - & - \\ 53^{\circ} \mathrm{N}-59^{\circ} \mathrm{N} & - & -\end{array}$

\section{Fall}

\begin{tabular}{rrc}
$29^{\circ} \mathrm{S}-13^{\circ} \mathrm{S}$ & - & - \\
$11^{\circ} \mathrm{S}-5^{\circ} \mathrm{N}$ & -15 & $1{ }^{\circ} \mathrm{N}$ \\
$7^{\circ} \mathrm{N}-15^{\circ} \mathrm{N}$ & 12 & $11^{\circ} \mathrm{N}$ \\
$17^{\circ} \mathrm{N}-51^{\circ} \mathrm{N}$ & -21 & $33^{\circ} \mathrm{N}$ \\
$17^{\circ} \mathrm{N}-39^{\circ} \mathrm{N}$ & - & - \\
$53^{\circ} \mathrm{N}-59^{\circ} \mathrm{N}$ & - & - \\
\hline
\end{tabular}

the southwestern Sargasso Sea region. The converse occurs in the tropics where annual variability exceeds interannual variability.

The VRM field for the IAN band, given in Fig. 7d, also shows a dramatic increase in variance above $50^{\circ} \mathrm{N}$ with the maximum variance just below Greenland. The smallest IAN band variance levels are found in the Sargasso Sea and in the tropics.

\section{b. Pentadal analyses}

Six successive pentadal averages from 1955 to 1984 , plus the 35-year averaged curl field spanning 1950-84, were compared (not shown). Most notable about these pentadal curl fields was their remarkable similarity. Two of these pentads (1955-59 and 1970-74) were compared with the Levitus (1989) pentadal water mass variability in the North Atlantic. The principal feature of the pentadal wind stress fields, while subtle, appears in the center of the subtropical gyre. Compared with 1970-74, the 1955-59 pentad shows that the western subtropical curl field contours extend farther east and that a slightly stronger region of positive curl appears north of the Gulf Stream. Of the entire group, the 197579 pentad, which includes the severe winter of 197677 (Leetmaa 1977; Worthington 1977), shows the curl field to be most developed in its areal extent over the subtropical gyre.

\section{c. Zonal integral sequences}

The basinwide effect of the regional variability of curl may be assessed by computing zonal integrals. These are presented in Fig. 8 as $\left.\psi\left(V_{\mathrm{S}}\right)\right|_{\mathrm{WB}}$ as a function of time and latitude, using a two-year running average over the whole record (1948-1988). The most obvious features are specific to the subtropical gyre near $31^{\circ} \mathrm{N}$, the tropical gyre near $9^{\circ} \mathrm{N}$, and the equatorial gyre near $1^{\circ} \mathrm{S}$. For the latter, there appears to be almost a secularly increasing decadal variation with a maximum centered on 1980. In the tropical gyre, a minimum appears in the late 1950 s and a maximum appears in the mid-1980s. In the subtropical gyre, a strong minimum is near 1970 with maxima near 1960, 1965, 1977 , and 1986. This would explain the subtlety in the pentadal analyses as pentadal averages appear to be too long to discern much of the higher frequency interannual variability.

The extent to which individual years contribute to the interannual variability can be obtained by plotting the envelope of seasonal transport extremes as represented by the sequence of winter and summer half years at selected latitudes. Such a rendering of the $\left.\psi\left(V_{\mathrm{S}}\right)\right|_{\text {WB }}$ field shows how the seasonal extremes for each year give rise to interannual variability. Pairs of curves for $1^{\circ} \mathrm{S}, 9^{\circ} \mathrm{N}$, and $31^{\circ} \mathrm{N}$ are in Fig. 9 a, and for $41^{\circ} \mathrm{N}$ and $31^{\circ} \mathrm{N}$ are in Fig. $9 \mathrm{~b}$. The latter shows the variability near $41^{\circ} \mathrm{N}$ and includes the cyclonic curl field [Figs. $3 c(i)$ and $3 c($ ii)] southeast of the Grand Banks off 

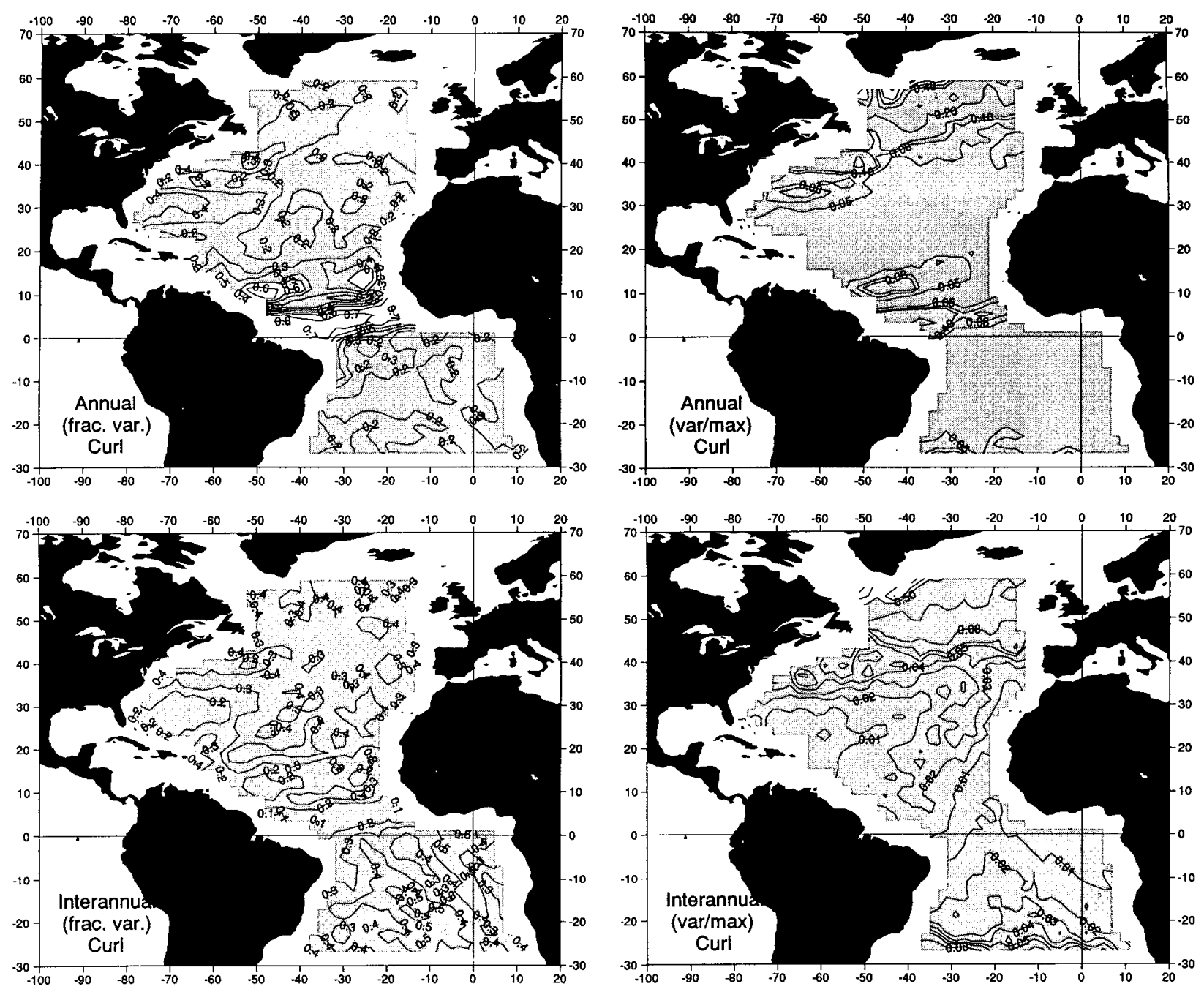

FIG. 7. Fractional variance (FVR) field (a) for annual frequency band and (c) for interannual frequency band of curl field normalized with respect to low-pass band. (b) Variance maximum (VRM) field for annual frequency band of curl field normalized with respect to maximum variance in annual band over the analysis domain. Contours $(0.05,0.08,0.1,0.2,0.4,0.5,0.6,0.8)$. (d) As in (b) but for interannual frequency band of curl field normalized with respect to maximum variance in interannual band over the analysis domain. Contours $(0.01,0.02,0.03,0.04,0.05,0.06,0.08,0.2,0.5,0.6,0.8)$.

Nova Scotia. In Fig. 9a, the summer half-year transports for the tropical and equatorial gyres are a maximum, as expected, and it is difficult to discern if interannual variability is more important in either winter or summer half years. In contrast, most of the interannual variability in the subtropical gyre can be accounted for by the winter half year. With regard to the

TABLE 3. Frequency bands (record length: $504 \mathrm{mo}, \Delta t: 1 \mathrm{mo}$ ). Resolution frequency, $\Delta f=42^{-1}$ cycles per year (cpy).

\begin{tabular}{clr}
\hline \hline Harmonics & \multicolumn{1}{c}{ Frequency band $(c p y)$} \\
\hline $1-91$ & Low-pass $(L P)$ & $42^{-1}-0.46^{-1}$ \\
$1-34$ & Interannual $(I A N)$ & $42^{-1}-1.24^{-1}$ \\
$35-49$ & Annual $(A N)$ & $1.20^{-1}-0.86^{-1}$ \\
\hline
\end{tabular}

pentads $1955-59$ and $1970-74$, there appears to be no difference in this measure of the wind-driven transport. For the severe winter of 1976-77, the transport is a maximum at $31^{\circ} \mathrm{N}$ (Fig. 9) but is almost the same as that registered in 1964, 1966, and 1988.

\section{Discussion}

Using COADS data spanning 42 years from 1947 through 1988, we have attempted to describe the surface meteorological and the implied wind-driven Sverdrup circulation fields for the Atlantic Ocean from $30^{\circ} \mathrm{S}$ to $60^{\circ} \mathrm{N}$. Such a simple wind-driven circulation model has many shortcomings: the solutions are depth independent; they exclude topography; and they do not address the thermohaline part of the circulation in ways 


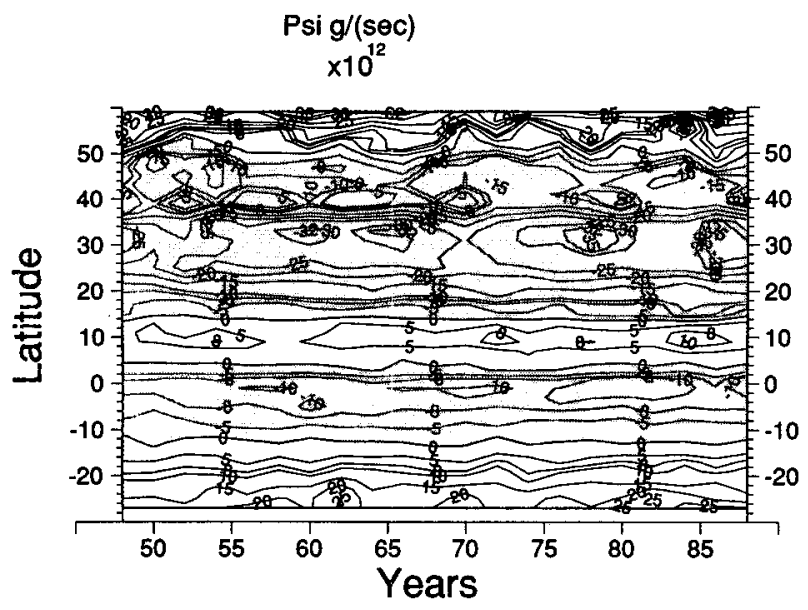

FIG. 8. Two-year average $\left.\psi\left(V_{\mathrm{S}}\right)\right|_{\mathrm{WB}}$ transport over full record (4I years).

other than wind-stress torque. Nevertheless, they do follow directly from the historical wind field and they provide important inferences with regard to the actual circulation fields.

By comparing the zonally integrated Sverdrup streamfunction and the wind-stress components at selected latitudes with those derived from the Hellerman and Rosenstein (1983) and the Isemer and Hasse (1987) climatologies, as given in Böning et al. (1991), reasonable agreements were found. This is encouraging in view of the constant air density and drag coefficient that were used to convert pseudostress to wind stress for COADS. Although not exhaustive, these comparisons do inspire some confidence in the COADS windstress fields as derived herein. As regards the tropics, similar analyses using HR winds (not shown) lead to similar inferences.

Our focus has been on the three central gyres in the Atlantic: the large anticyclonic subtropical gyre; the cyclonic tropical gyre to the north of the equator, which has the smallest meridional extent of the three; and the clockwise equatorial gyre, which straddles the equator. Discussions are given on fields of the annual cycle of Sverdrup transport and annual and interannual variability of the wind-stress curl.

\section{a. Overall mean and annual cycle of the Sverdrup transport fields}

The annual mean Sverdrup transport in the subtropical gyre from COADS is given in Table 1 and Fig. 4b. A maximum transport of $-31 \mathrm{Mt} \mathrm{s}^{-1}$ at $31^{\circ} \mathrm{N}$ is embedded within a broad maximum extending from $29^{\circ} \mathrm{N}$ to $33^{\circ} \mathrm{N}$. Leetmaa and Bunker (1978) calculated $-32 \mathrm{Mt} \mathrm{s}^{-1}$ at $31^{\circ} \mathrm{N}$. At $26.5^{\circ} \mathrm{N}$, the transport falls within the range -25 to $-28 \mathrm{Mt} \mathrm{s}^{-1}$ (derived from the modified grid described in section $4 \mathrm{a}$ ), which compares favorably with the volume transport of $31.5 \mathrm{~Sv}$ reported by Lee et al. (1990) for the Straits of Florida using a composite of dropsonde and PEGASUS observations. These observations necessarily include the thermohaline component that is controlled by other factors (Schmitz and Richardson 1991). They indicate a thermohaline component of greater than $10 \mathrm{~Sv}$ through the Straits of Florida. Despite this, the transport from observations and COADS at this latitude $\left(26^{\circ} \mathrm{N}-27^{\circ} \mathrm{N}\right)$ are within $6 \mathrm{~Sv}$ of each other. Also at $26^{\circ} \mathrm{N}$, an integration of HR winds for 1983 (Lee et al. 1990) resulted in a transport of $-26 \mathrm{Mt} \mathrm{s}^{-1}$, which is close to the climatological average [Fig. 4c(i)] using HR winds and within the range of that estimated from the 42-year COADS average.

The climatological annual cycle of the subtropical gyre (near $26^{\circ} \mathrm{N}-27^{\circ} \mathrm{N}$ ) is represented in Fig. $6 \mathrm{c}$ by a broad maximum in winter of roughly $-40 \mathrm{Mt} \mathrm{s}^{-1}$, a relative maximum in summer of about $-35 \mathrm{Mt} \mathrm{s}^{-1}$, and a minimum, due to the collapse of the curl field in October, of about $-20 \mathrm{Mt} \mathrm{s}^{-1}$ (about a $20 \mathrm{Mt} \mathrm{s}^{-1}$ change from peak to trough). From Lee et al. (1990), their application of the Anderson and Corry (1985) model using $\mathrm{HR}$ winds at $26^{\circ} \mathrm{N}$ produced a similar annual variation, but without the relative maximum in summer, presumably because the Sverdrup circulation at this latitude cannot respond at semiannual frequencies. Analyses of their mooring data further showed no evidence of significant annual variation of volume transport in boundary currents east of the Bahamas.

Within the Straits of Florida the annual cycle is considerably different from that suggested by the interior Sverdrup transports, particularly in winter. Observations of Straits of Florida transports can be characterized by a rapid change of about $6 \mathrm{~Sv}$ from a broad spring and summer maximum peaking in August to a minimum in October (Schott et al. 1988; Rosenfeld et al. 1989; Böning et al. 1991). Recently, as described by Thompson et al. (1991), the amplitude of Straits of Florida transport has been successfully modeled when the thermohaline circulation proposed by Schmitz and Richardson (1991) is specified as a source-sink flow. However, numerical models of Straits of Florida transport have been successful in reproducing the correct phase of this observed variation, but many have underestimated the amplitude. Rosenfeld et al. (1989) discussed some of the physical mechanisms that might account for these variations. Among them are regional winds, an idea that may be explored using COADS winds. Using a 6.5-year record of sea level difference across the straits near $26.5^{\circ} \mathrm{N}$ from 1982 to 1988, Mayer and Maul (1991) showed that a frequency-dependent statistical model relating SLD to Straits of Florida volume transport, as observed with submarine cable voltages, could account for nearly $80 \%$ of the variance of observed cable voltage in the annual to semiannual frequency band. With SLD thus serving as a proxy for Florida Current volume transport, cross- 


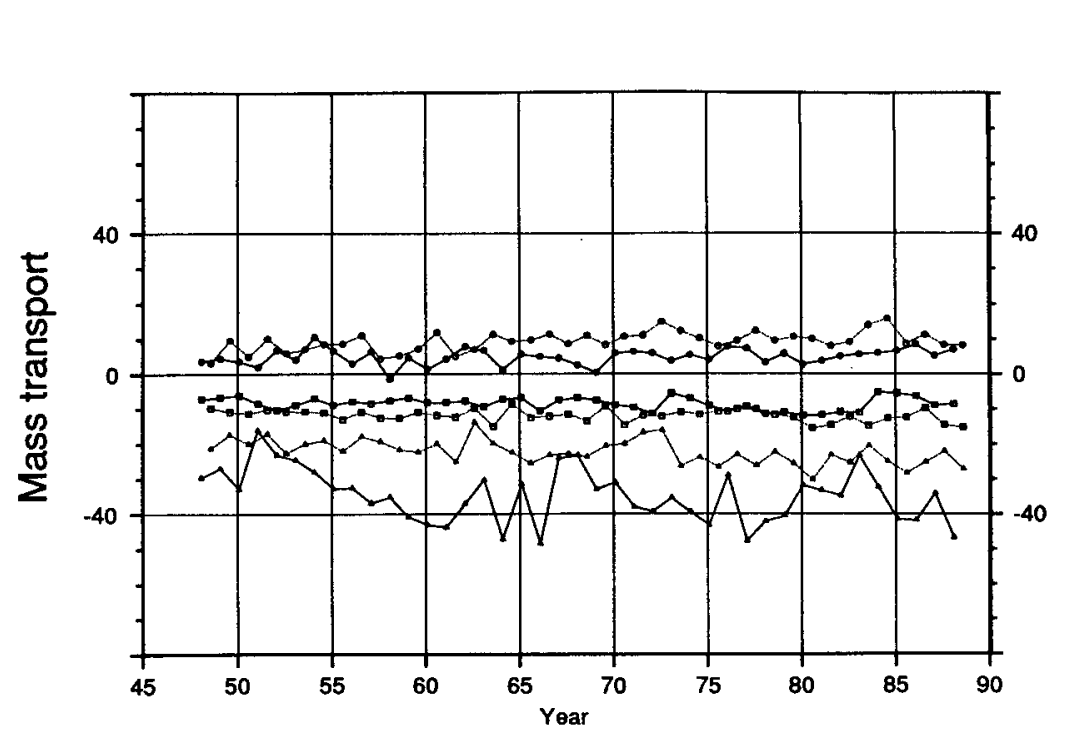

[] 15

(1) $9 \mathrm{~N}$

$\triangle 31 N$

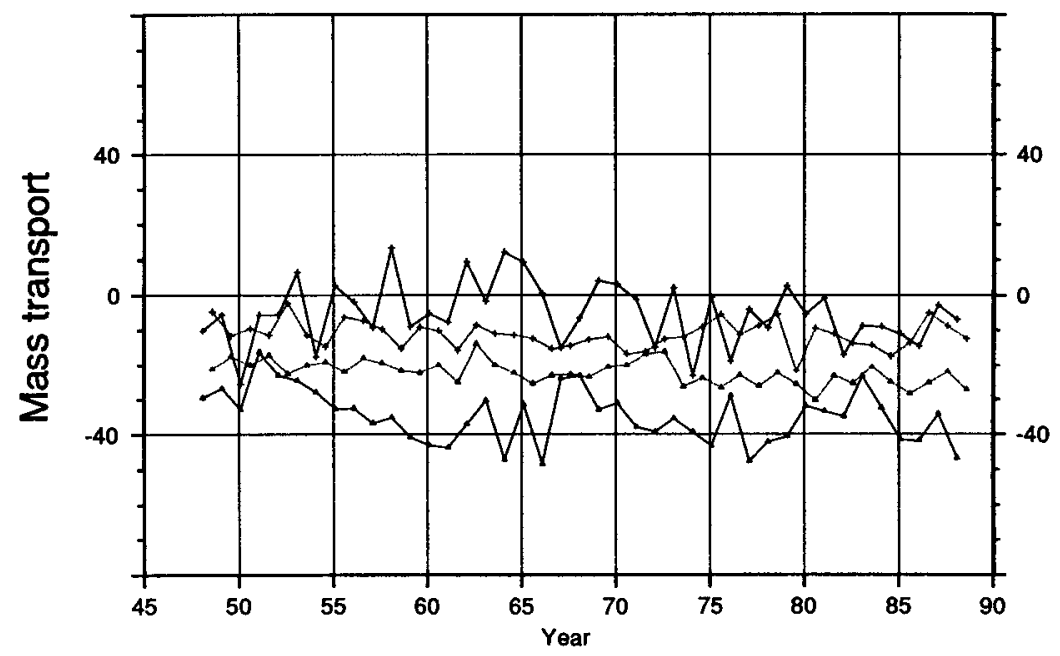

FIG. 9. Winter (solid) and summer (dotted) half-year $\left.\psi\left(V_{\mathrm{S}}\right)\right|_{\mathrm{wB}}\left[\right.$ units: $\left.\mathrm{g} \mathrm{s}^{-1} \times 10^{12}\left(\mathrm{Mt} \mathrm{s}^{-1}\right)\right]$ for (a) $1^{\circ} \mathrm{S}, 9^{\circ} \mathrm{N}, 31^{\circ} \mathrm{N}$ and (b) for $31^{\circ} \mathrm{N}, 41^{\circ} \mathrm{N}$.

spectral analyses were performed between it and the COADS time series over the bandwidth $393^{-1}$ to $182^{-1}$ days $^{-1}$ (Mayer and Maul 1991). Examined this way were 111 time series of zonal integrals of $V_{\mathrm{S}}$, windstress curl, and wind-stress vectors for selected areas in the Caribbean, the Gulf of Mexico, and the western Atlantic from $4^{\circ} \mathrm{N}$ to $38^{\circ} \mathrm{N}$. The bandwidth results in about 17 degrees of freedom and a 95\% significance level on coherence squared of $\gamma^{2}=0.3$. The most coherent relationships between SLD and the COADS time series were obtained with wind stress from the western Atlantic region north of the straits between $27^{\circ} \mathrm{N}$ and $33^{\circ} \mathrm{N}$. Maximum coherence $\left(\gamma^{2}>0.6\right)$ occurred with the shore-parallel wind-stress component, together with an orderly phase progression southward along the coast. For example, SLD in the straits lags the shore-parallel wind-stress component at $33^{\circ} \mathrm{N}$ by about one month. This suggests that a part of the SLD signal in the straits is an integrated response to the wind-stress forcing that occurs northward along the coast. These results are consistent with the Anderson and Corry (1985) suggestion that coastally trapped waves generated to the north of the straits are important for the annual cycle of transport within the straits ( Rosenfeld et al. 1989).

The cyclonic tropical gyre to the north of the equator has a mean meridional position between $5^{\circ} \mathrm{N}$ and $13^{\circ} \mathrm{N}$. On annual average, a return flow within an SEBC, as implied by the Sverdrup interior transport, would peak near $11^{\circ} \mathrm{N}$ at about $-9 \mathrm{Mt} \mathrm{s}^{-1}$ (Table 1). 
However, such a southeastward flowing boundary current has not been reported in the literature. To the contrary, inference from ship drift climatology (Richardson and Walsh 1986) and numerical model results (e.g., Philander and Pacanowski 1986a) suggest a continuous northwestward flowing boundary current connecting the NBC with the Caribbean in wintertime via the GC. Since the NBC is the western boundary current providing closure for the clockwise equatorial gyre, this scenario of continuous flow into the Caribbean circumvents, entirely, the notion of a cyclonic tropical gyre. Something is clearly amiss, at least along the vein of the Sverdrup circulation. Limited surface float tracks reported by Richardson and Reverdin (1987) support the contention of continuous surface flow, but they are inconclusive. The distribution of surface salinity also presents a dilemma. The Caribbean is characterized by relatively low surface salinity; however, waters of Amazon River origin are found far offshore and it remains unclear whether Caribbean salinities are influenced more by the Orinoco River or by a combination of both rivers, that is, Muller-Karger et al. (1988) and Ryther et al. (1967). One problem in resolving these issues is the paucity of data northwest of $8^{\circ} \mathrm{N}, 58^{\circ} \mathrm{W}$, the region where a western boundary current connecting the tropical gyre with the Caribbean would be located, if one exists. Another problem is the large seasonal cycle in both the latitudinal position and the magnitude for this tropical gyre. While the gyre is present year round (Fig. 6c), the latitude of the gyre center, and its peak transport, shifts from $5^{\circ} \mathrm{N}$ with about 10 $\mathrm{Mt} \mathrm{s}^{-1}$ in winter to $11^{\circ} \mathrm{N}$ with about $22 \mathrm{Mt} \mathrm{s}^{-1}$ in summer: this shift following the seasonal position of the ITCZ, or approximately the zero contour of the streamfunction field (Fig. 5e). Thus, in summer, the tropical gyre is well defined and farthest north, with the NBC retroflecting into the NECC between $3^{\circ} \mathrm{N}$ and $10^{\circ} \mathrm{N}$ while, in winter, on the western side of the basin, the tropical gyre is less defined and farthest south [Fig. 5e(i)], with the NEC shifting southward to the position previously occupied by the NECC, thereby accounting for the reversal of the NECC within that latitude band as described by Garzoli and Katz (1983). Velocity measurements from the equator in the westcentral Atlantic are also consistent with this southward shift in the streamfunction field. During the winter months of 1983,1984 , and 1985 , as reported by Weisberg et al. (1987), the surface currents at $0^{\circ}, 28^{\circ} \mathrm{W}$ tended to be eastward and contiguous with the equatorial undercurrent (EUC) at the same time that the easterly winds were a minimum and SST was a maximum, both consistent with the ITCZ being located farthest south. During the winter months of 1984 , Hisard et al. (1986) also reported eastward surface currents along $23.5^{\circ} \mathrm{W}$ between $4^{\circ} \mathrm{S}$ and $1^{\circ} \mathrm{N}$. Upon summing the SEC and the EUC transports in the Philander and Pacanowski (1986a) numerical model, a maximum eastward transport is also found on the equator during late winter and this is similar to the Katz et al. (1981) finding using shipboard-derived velocity composites. With the NBC feeding increased eastward flows on the equator, in winter, there is no need for a strong northwestward-directed NBC to the north of the equator. Northwestward flow observed farther to the north, in winter, may simply be an extension of the NEC, and hence a part of the subtropical gyre, not the tropical gyre.

Recent observations and models remain equivocal on the issue of western boundary closure for the cyclonic tropical gyre. Schott and Böning (1991) describe an equatorward undercurrent off Guiana in the depth range of 100-300 $\mathrm{m}$ in their analysis of the WOCE, CME model, and they question the connection of crossequatorial NBC flow into the GC and Caribbean. The Johns et al. (1990) data do not show a connection of the NBC with the GC and Caribbean in spring, at least seaward of the 1000-m isobath. However, Chereskin and Roemmich (1991) observed strong northwestward flow in March near $5^{\circ} \mathrm{N}, 51^{\circ} \mathrm{W}$ on the shallow shelf off French Guiana.

The clockwise equatorial gyre whose return flow is the NBC has a mean meridional position between $11^{\circ} \mathrm{S}$ and $3^{\circ} \mathrm{N}$. The annual average return flow peaks near $3^{\circ} \mathrm{S}$ at $11 \mathrm{Mt} \mathrm{s}^{-1}$. The latitude of peak transport shifts in winter from $3^{\circ} \mathrm{S}$ with a transport of about $-8 \mathrm{Mt} \mathrm{s}^{-1}$ (a minimum) to $3^{\circ} \mathrm{N}$ with a transport of about -15 $\mathrm{Mt} \mathrm{s}{ }^{-1}$ when it is a maximum in summer. In summer [Fig. 5e(ii)] near $30^{\circ} \mathrm{W}$, an eastward flow (SECC) is indicated in the streamfunction field between about $1^{\circ} \mathrm{S}$ to $5^{\circ} \mathrm{S}$. This is consistent with the observations of Molinari (1983) and with the model results of Schott and Böning (1991), who describe an eastward flow in summer concentrated over about $2^{\circ}$ of latitude near $2^{\circ} \mathrm{S}$.

It is within the cyclonic tropical gyre and the clockwise equatorial gyre that the large annual cycles in the atmospheric and the upper-ocean temperature and current fields are observed. For example, SST along the equator, particularly between $5^{\circ} \mathrm{W}$ and $15^{\circ} \mathrm{W}$, varies by up to $8^{\circ} \mathrm{C}$ between the appearance of cold SST beginning in spring, relative to the warm and zonally more homogeneous SST conditions in winter (e.g., Weisberg and Tang 1990; Weingartner and Weisberg 1991). An atmospheric manifestation is clearly evident in the div fields of Figs. 3d(i)-(iii). The cold water tongue splits an equatorially symmetric div field existing in winter into a separate Northern Hemisphere ITCZ and a Southern Hemisphere South Atlantic convergence zone (SACZ) in summer. The SACZ subsequently dissipates by fall as SST continues to cool to the south of the equator. By virtue of SST and the associated div fields, the tropical and equatorial gyres influence climate both regionally and globally. Regionally, the positions and strengths of the ITCZ and the SACZ impact upon rainfall over the African Sahel and the Brazilian Nordeste, with interannual variability 
giving rise to severe drought conditions. Globally, the annually averaged heat flux from the Southern into the Northern Hemisphere, as part of the Atlantic Ocean's overturning mode of circulation, increases by a factor of about 1.5 across the equator, due to the cold SST there. By influencing the convergence zones and increasing meridional heat flux, SST is the common thread linking the regional and global climate issues within the tropical and equatorial gyres.

Given the annual cycle in SST and the strengths and locations of the tropical and equatorial gyres, how do these gyres communicate to bring about an annually averaged northward heat flux? Geostrophic analyses by Roemmich (1983) at $8^{\circ} \mathrm{N}$ and $8^{\circ} \mathrm{S}$ show that the overturning mode of circulation at these latitudes consists of a net northward, near-surface circulation of about $10 \mathrm{~Sv}$, which when added to the northward flowing Antarctic Intermediate Water is balanced by the southward flowing North Atlantic Deep Water. Within the surfacemost layers, geostrophic flow is convergent upon the equator and this is compensated for by an Ekman layer divergence. In calculating the net heat flux, as the sum of the Ekman and the geostrophic components, a jump of about $0.9 \mathrm{PW}$ was obtained across the equatorial band with the Ekman layer then being the dominant transporter of heat at $8^{\circ} \mathrm{N}$. The implication of these zonally averaged analyses is that near-surface water upwells within the band of plus and minus $8^{\circ}$ latitude, is warmed, and is then advected northward by Ekman transport. Using a climatological wind-forced numerical model Sarmiento (1986) arrived at similar results. On annual and zonal average, when partitioned into barotropic, baroclinic, and Ekman heat transports, the northward-directed baroclinic and barotropic transports at $8^{\circ} \mathrm{S}$ give way primarily to Ekman transport at $8^{\circ} \mathrm{N}$ in accounting for the interhemispheric transport of heat. Qualitatively, the related mass flux would be similar to the Sverdrup transport analyses given in Fig. 4b. Philander and Pacanowski (1986a,b), also using a numerical model, provide further insight into the mechanisms of transport. By plotting zonally averaged northward heat transport as a function of time and latitude, they show that the heat flux past $8^{\circ} \mathrm{N}$ is a minimum in summer when the tropical and equatorial gyres are most developed and a maximum in winter when these gyres relax. Analogy is drawn to a capacitor storing heat between $5^{\circ} \mathrm{S}$ and $8^{\circ} \mathrm{N}$ in summer while the thermocline is deep and releasing heat to the region $8^{\circ} \mathrm{N}-15^{\circ} \mathrm{N}$ in winter as the thermocline deepens. The NBC within their model is shown to be a continuous feature connecting the tropics with the Caribbean, and this current is given as the conveyance for the northward flux of heat in winter. A drawback of this last finding is the size of the control volumes analyzed. Their westernmost box extended from the South American coast to $30^{\circ} \mathrm{W}$, and, since $30^{\circ} \mathrm{W}$ is a midbasin position between $2.5^{\circ} \mathrm{N}-8^{\circ} \mathrm{N}$, as opposed to a western boundary position, the transport out of that box is not necessarily a western boundary current transport. Further evidence is provided by Levitus (1987), who estimated a zonally integrated Ekman layer heat transport using a surface minus depth-averaged potential temperature difference. At $9^{\circ} \mathrm{N}$, the northward Ekman heat transport ranged from about $1.5 \mathrm{PW}$ in winter to zero in summer in agreement with the previous numerical model and the geostrophic calculations.

While there is consensus on the magnitude and the seasonality of the interhemispheric heat flux, the mechanism(s) by which this heat is transported remains unresolved. The following hypothesis is adduced. As suggested by Philander and Pacanowski (1986b), the gyres do behave like capacitors. Heat and mass are stored within the NECC ridge during summer; this ridge being set up directly by Ekman layer convergence [Figs. 5a(ii) and 5b(ii)] and subsequently by the NBC retroflection in summer, which transports additional warm water into the NECC. At the same time, and in similar ways, the NEC trough is developed serving as a dynamical barrier to a farther northward heat flux. In winter, as the ITCZ migrates southward toward the equator and the tropical and equatorial gyres relax, the heat that had been stored within the NECC ridge is transported northward within the Ekman layer, primarily over the western half of the basin [Figs. 5a(i) and $5 \mathrm{~b}(\mathrm{i})]$. The physics envisaged thus involve both western boundary currents and wind-stress torques but during different times of year. In summer, the western boundary current (the NBC) is instrumental in carrying warm water to the latitudes between the NECC ridge and the NEC trough (roughly $3^{\circ} \mathrm{N}-9^{\circ} \mathrm{N}$ ). Fluid within the NBC can accomplish its equatorial crossing as an inertial jet, gaining relative vorticity and retroflecting into the NECC as explained, for example, by Pedlosky (1987). Once this heated water pervades the interior of the basin, it is stored there until winter, when the change in wind-stress torque enables it to move farther north by Ekman transport as the NEC trough opens up, allowing vortex tubes to stretch over the region where the water is warmest. This two-staged hypothesis, which includes western boundary current transports in summer and gyre interior Ekman transports in winter, is consistent with the ideas put forth earlier, simply piecing them together into a composite annual cycle. Once the warm surface waters reach beyond the latitude of the tropical gyre, they are then swept up by the NEC, a portion of which may become part of a coastal confined GC. This hypothesis gains support from the recent findings of Schmitz and Richardson (1991). Using water mass analyses they argue that about $7 \mathrm{~Sv}$ within the upper $100 \mathrm{~m}$ (temperatures $>24^{\circ} \mathrm{C}$ ) of the Florida Current is composed of relatively fresh water issuing from the South Atlantic, but not as a direct contribution from the NBC.

While Ekman transport may be the principal intergyre exchange mechanism between the tropical and subtropical gyres, this does not appear to be the case between the subtropical and subpolar gyres (Fig. 5a). 
On the northern side of the subtropical gyre, $V_{e}$ is much smaller than it is in the tropics and it is directed southward. Warm core rings (Brown et al. 1986) and other eddies and filaments on the northern side of the Gulf Stream provide plausible intergyre exchange mechanisms there.

\section{b. Annual and interannual variability of the wind- stress curl}

Annual and interannual variability for the curl field in the Atlantic Ocean are both maximum north of $50^{\circ} \mathrm{N}$. Different regions, however, have distinctively different annual and interannual behavior. In the AN band, four active regions have been identified with roughly the same energy levels (two in the subtropics and two in the tropics). These are confined to the central and western Atlantic, whereas the southern portion of the northern subtropical gyre and the Southern Hemisphere subtropical gyre both show minimal annual variability. In the IAN band, the active regions are outside the tropics in the central and eastern North Atlantic and in the South Atlantic.

Motivated by the Levitus (1989) analysis of North Atlantic water masses for the two pentads 1955-59 and 1970-74 and his suggestion that changes in the curl field may have effected the observed isopycnal shoaling, pentadal averages were performed for the curl fields. Variations among these pentadal curl fields were subtle and only over limited areas and therefore of little use in accounting for water mass changes. This is discussed below.

Talley and Raymer ( 1982) note that convective formation of $18^{\circ} \mathrm{C}$ Water in the north-central Sargasso Sea virtually ceased from 1972 to 1975 . If deep winter convection, as hypothesized by Worthington (1977), is one of the principal mechanisms causing changes in the intensity of the Gulf Stream gyre, then as suggested by Levitus (1989), the Gulf Stream transport may have been lower in 1970-74 compared with 1955-59. Observational evidence that late winter convection caused a large increase in Gulf Stream transport after the severe winter of $1976 / 77$ was a possibility noted by Worthington (1977). Leetmaa (1977) has noted that the atmosphere, in the course of one winter, can dramatically affect the baroclinic volume transports in the northwestern Sargasso Sea. In Fig. 9, the quantity $\left.\psi\left(V_{\mathrm{S}}\right)\right|_{\mathrm{WB}}$, which represents the maximum net winddriven transport for winter and summer half years, has been plotted for the latitude associated with each of the gyres in the Atlantic Ocean. Clearly shown are the year-to-year variability of the winter extremes and their contributions to the pentadal averages. In addition, the winter half-year sequence at $31^{\circ} \mathrm{N}$ shows that most of the subtropical interannual variability in transport occurs in winter. This, along with the Maul and Hanson (1991) NAO and composite sea level analysis, shows that most of the interannual variance is accounted for by the winter-only NAO signal. In comparing the two 5-yr periods $1955-59$ and $1970-74$, no significant dif- ferences in wintertime transport are manifest. Both periods look similar, showing an irregular but persistent five-year increase in transport. The effects of the severe winter on the total transport in 1977 appears as a maximum, but no more so than several other years (1964, 1966,1988 ). Worthington (1977) states that the windstress curl field alone, for the winter of 1977 , could not account for the unprecedented increase in baroclinic Gulf Stream transport. He further notes that, after the mild winter of $1974 / 75$, the Gulf Stream transport was near the minimum volume transport ever computed. Referring to Fig. 9 again, for the winter of $1974 / 75$, the transport at $31^{\circ} \mathrm{N}$ from the winter half-year sequence is closer to a maximum than to a minimum. Clearly, factors other than the curl of the wind stress, such as Worthington's (1977) hypothesis, must be invoked to account for the interannual variability of Gulf Stream transport.

In considering the possibility that annual and interannual variability in nonadiabatic convective processes play a role in Gulf Stream transport, Talley and Raymer (1982) did not find a strong correlation, at least through the year 1972 , between $18^{\circ} \mathrm{C}$ Water formation and heat flux in a region $34^{\circ} \mathrm{N}-36^{\circ} \mathrm{N}, 65^{\circ} \mathrm{W}-70^{\circ} \mathrm{W}$. They did show, however, a low potential vorticity water mass at $55^{\circ} \mathrm{W}$ in July 1977 and suggested that it was formed to the west in the late winter of 1977. It is possible that the ship of opportunity heat flux parameterizations did not adequately account for the ensemble of winter cyclones that may occur (as described for the New York Bight by Mooers et al. 1976). Mayer et al. (1982) document that the sequence of cyclones was particularly intense during the winter of $1976 / 77$, and since the winter cyclone activity in the region $35^{\circ} \mathrm{N}-$ $45^{\circ} \mathrm{N}, 60^{\circ} \mathrm{W}-75^{\circ} \mathrm{W}$ has a frequency and duration of roughly $5 \mathrm{mo}^{-1}$ and 2 days, (Mooers et al. 1976), sampling by ships of opportunity may not be reasonable.

\section{Recapitulation}

The following points provide a summary in the order that they have been discussed.

1) The Sverdrup streamfunction field derived from COADS compares favorably with other climatologies (Hellerman and Rosenstien 1983; Isemer and Hasse 1987). From COADS, a maximum transport at $31^{\circ} \mathrm{N}$ of $-31 \mathrm{Mt} \mathrm{s}^{-1}$ is consistent with the computation of Leetmaa and Bunker (1978). At $27^{\circ} \mathrm{N}$, the transport falls within the range -25 to $-28 \mathrm{Mt} \mathrm{s}^{-1}$ compared with a volume transport of $31.5 \mathrm{~Sv}$ reported by Lee et al. (1990) from direct observations in the Straits of Florida.

2) Direct evidence of the annual cycle in Sverdrup transport within the subtropical gyre $\left(26^{\circ} \mathrm{N}-27^{\circ} \mathrm{N}\right)$ implied by climatological winds remains elusive (Lee et al. 1990). The winds suggest a double maximum in both winter $\left(-40 \mathrm{Mt} \mathrm{s}^{-1}\right)$ and summer $\left(-30 \mathrm{Mt} \mathrm{s}^{-1}\right)$ with a collapse of the transport in the fall to about -20 
$\mathrm{Mt} \mathrm{s}^{-1}$. The lack of observational or model support of such semiannual transport variations alludes to the baroclinic adjustment time at these latitudes.

3) Observations of transport in the Straits of Florida can be characterized by a rapid change of about $6 \mathrm{~Sv}$, from a broad spring and summer maximum peaking in August to a minimum in October and November (Schott et al. 1988; Rosenfeld et al. 1989). The shoreparallel component of COADS wind stress north of the straits is coherent with SLD in the straits, where SLD is a proxy for Straits of Florida volume transport (Mayer and Maul 1991). This supports the notion that coastally trapped waves generated to the north of the straits (Anderson and Corry 1985) are one of several mechanisms that play a significant role in the annual cycle of transport in the straits (Rosenfeld et al. 1989; Thompson et al. 1991).

4) Intergyre and interhemisphere exchange of nearsurface waters in the tropical Atlantic is climatically important on both regional and global scales. Several inferences follow directly from the COADS Sverdrup circulation fields. Of particular interest is the cyclonic tropical gyre, separating the anticyclonic Northern Hemisphere subtropical gyre and the clockwise equatorial gyre. Closure of the Sverdrup interior transport for the tropical gyre implies an SEBC, which is opposite to the notion of continuous northwestward boundary flow carrying fluid directly from the equator region into the Caribbean during winter. The COADS data, together with a review of the pathways of heat and mass from observations and numerical models (e.g., Roemmich 1983; Levitus 1987; Sarmiento 1986; Philander and Pacanowski 1986a,b), allows us to hypothesize a composite annual cycle that accommodates interhemisphere and intergyre exchange in a manner consistent with a cyclonic tropical gyre. The physics envisaged involve both a western boundary current and wind-stress torques, but with primary influence during different times of the year. In summer, the western boundary current (the NBC) is instrumental (in concert with Ekman convergence) in carrying heated water to the latitudes between the NECC ridge and the NEC trough ( roughly $3^{\circ} \mathrm{N}-9^{\circ} \mathrm{N}$ ). Fluid within the NBC can accomplish its equatorial crossing as an inertial jet, gaining relative vorticity and retroflecting into the NECC as explained by Pedlosky (1987), for example. Once this heated water pervades the interior of the basin, it is stored there until winter, when the change in wind-stress torque enables it to move farther north by Ekman transport as the NEC trough opens up, allowing vortex tubes to stretch over the region where the water is warmest. This two-staged hypothesis (including western boundary current transports in summer and gyre interior Ekman transports in winter) is consistent with previous ideas, simply piecing them together into a composite annual cycle. Once the warm surface waters get beyond the latitude of the tropical gyre they are then swept up by the NEC, a portion of which may become part of a coastal confined GC. This hypothesis gains support from the recent findings of Schmitz and Richardson (1991). They argue that about $7 \mathrm{~Sv}$ within the upper $100 \mathrm{~m}$ ( temperatures $>24^{\circ} \mathrm{C}$ ) of the Florida Current is composed of relatively fresh water issuing from the South Atlantic, but not as a direct contribution from the NBC.

5) While Ekman transport may be the principal intergyre exchange mechanism between the tropical and subtropical gyres, this does not appear to be the case between the subtropical and subpolar gyres (Fig. 5a). On the northern side of the subtropical gyre, $V_{e}$ is much smaller than it is in the tropics and it is directed southward. Warm core rings (Brown et al. 1986) and other eddies and filaments on the northern side of the Gulf Stream provide plausible intergyre exchange mechanisms there. The inference from the COADS data then is that distinctly different physics control the exchange of near-surface waters between the anticyclonic Northern Hemisphere subtropical gyre with its neighboring cyclonic gyres to the north and south.

6) Annual (AN) and interannual (IAN) wind-stress curl variances are both maximum in the Atlantic Ocean north of $50^{\circ} \mathrm{N}$. The AN band shows four other active regions, two in the subtropics and two in the tropics (but with energy levels an order of magnitude less than in the subpolar region). IAN band variance exceeds AN band variance by at least a factor of 1.5 throughout the central and eastern North Atlantic outside the tropics and throughout the South Atlantic.

7) Pentadal analyses of wind-stress curl were not useful in accounting for the shoaling density surfaces in the subtropical gyre between the 1970-74 and 195559 pentads, as described by Levitus (1989). From the works of Worthington (1977), Leetmaa (1977), and Talley and Raymer (1982) it would appear that late winter convection is an important determinant of interannual Gulf Stream transport variations. However, Talley and Raymer (1982) do not find a correlation between the formation of $18^{\circ} \mathrm{C}$ Water and heat flux over that region. A possible explanation is that the parameterization of heat flux based on ship of opportunity data provides inadequate temporal and spatial sampling of the ensemble of winter cyclones (Mooers et al. 1976) that pass over the formation zone of $18^{\circ} \mathrm{C}$ Water.

Acknowledgments. We would like to thank Scott Woodruff from CRD in Boulder for providing the COADS data, Michael Minton from AOML in Miami for his work in setting up the permanent COADS data files, and Bill Johns from RSMAS in Miami for his many helpful suggestions and encouragement during the evolution of this manuscript.

\section{REFERENCES}

Anderson, D. L. T., and R. A. Corry, 1985: Seasonal transport variations in the Florida Straits: A model study. J. Phys. Oceanogr., 15, 773-786

Bjerknes, J., 1964: Atlantic air-sea interaction. Advances in Geophysics, Vol. 10, Academic Press, 1-82. 
Böning, C. W., R. Döscher, and H. J. Isemer, 1991: Monthly mean wind stress and Sverdrup transports in the North Atlantic: A comparison of the Hellerman-Rosenstein and Isemer-Hasse climatologies. J. Phys. Oceanogr., 21, 221-235.

Brown, O. B., P. C. Cornillon, S. R. Emmerson, and H. Mark Carle, 1986: Gulf Stream warm rings: A statistical study of their behavior. Deep-Sea Res., 33, 1459-1473.

Chereskin, T. K., and D. Roemmich, 1991: A comparison of measured and wind-driven Ekman transport at $11^{\circ} \mathrm{N}$ in the Atlantic Ocean. J. Phys. Oceanogr., 21, 869-878.

Csanady, G. T., and P. Hamilton, 1988: Circulation of slopewater. Contin. Shelf Res., 8, 565-624.

Garzoli, S. L., and E. J. Katz, 1983: The forced annual reversal of the Atlantic North Equatorial Countercurrent. J. Phys. Oceanogr., 13, 2082-2090.

Hastenrath, S., and P. J. Lamb, 1977: Climatic Atlas of the Tropical Atlantic and Eastern Pacific Ocean. The University of Wisconsin Press, 25 pp., 97 charts.

Hellerman, S., and M. Rosenstein, 1983: Normal monthly wind over the world ocean with error estimates. J. Phys. Oceanogr., 13, 1093-1104.

Hisard, P., C. Henin, R. Houghton, B. Piton, and P. Rual, 1986: Oceanic conditions in the tropical Atlantic during 1983 and 1984. Nature, 322, 243-245.

Isemer, H. J., and L. Hasse, 1987: The Bunker Climate Atlas of the North Atlantic Ocean. Vol. 2, Air-Sea Interactions, SpringerVerlag, $256 \mathrm{pp}$.

Johns, W. E., T. N. Lee, F. A. Schott, R. J. Zantopp, and R. H. Evans, 1990: The North Brazil Current retroflection: Seasonal structure and eddy variability. J. Geophys. Res., 95(C12), 22 103-22 120 .

Katz, E. J., R. L. Molinari, D. E. Cartwright, P. Hisard, H. U. Lass, and $A$. de Mesquita, 1981: The seasonal transport of the equatorial undercurrent in the western Atlantic (during the Global Weather Experiment). Oceanol. Acta, 4, 445-450.

Lee, T. N., W. E. Johns, F. A. Schott, and R. J. Zantopp, 1990: Western boundary current structure and variability east of Abaco, Bahamas at $26.5^{\circ} \mathrm{N}$. J. Phys. Oceanogr., 20, 446-466.

Leetmaa, A., 1977: Effects of the winter of 1976-1977 on the northwestern Sargasso Sea. Science, 198, 188-189.

- and A. F. Bunker, 1978: Updated charts of the mean annual wind stress, convergences in the Ekman layers and Sverdrup transports in the North Atlantic. J. Mar. Res., 36(3), 311-322.

Levitus, S., 1987: Meridional Ekman heat fluxes for the world ocean and individual ocean basins. J. Phys. Oceanogr., 17, 1484-1492.

- 1988: Ekman volume fluxes for the world ocean and individual ocean basins. J. Phys. Oceanogr., 18, 271-279.

- 1989: Interpentadal variability of temperature and salinity at intermediate depths of the North Atlantic Ocean, 1970-1974 versus 1955-1959. J. Geophys. Res., 94(C5), 6091-6131.

Maul, G. A., and K. Hanson, 1991: Interannual coherence between North Atlantic atmospheric surface pressure and composite southern USA sea level. Geophys. Res. Lett., 18, 653-656.

Mayer, D. A., and G. A. Maul, 1991: Refinement of the statistical relationship between Straits of Florida sea level difference and Florida-Bahamas cable voltages. J. Geophys. Res., 96(C3), 4971-4972.

- G. C. Han, and D. V. Hansen, 1982: Circulation in the Hudson Shelf Valley: MESA physical oceanographic studies in New York Bight, 1. J. Geophys. Res., 87, 9563-9578.

- R. L. Molinari, and R. H. Weisberg, 1990: Analysis of volunteer observing ship temperature fields in the tropical Atlantic Ocean. Oceanol. Acta, 13(3), 257-264.

Merle, J., and S. Arnault, 1985: Seasonal variability of the surface dynamic topography in the tropical Atlantic Ocean. J. Mar. Res., 43, 267-288.

Molinari, R. L., 1983: Observations of near-surface currents and temperature in the central and western tropical Atlantic Ocean. J. Geophys. Res., 88(C7), 4433-4438.

Mooers, C. N. K., J. Fernandez-Partagas, and J. F. Price, 1976: Me- teorological forcing fields of the New York Bight. RSMAS Tech. Rep. TR76-8, University of Miami, RSMAS, 4600 Rickenbacker Causeway, 33149, Miami, FL, $151 \mathrm{pp}$.

Muller-Karger, F. E., C. R. McClain, and P. L. Richardson, 1988: The dispersal of the Amazon's water, Nature, 333, 56-59.

Pedlosky, J., 1987: Geophysical Fluid Dynamics. 2d ed. SpringerVerlag, $624 \mathrm{pp}$

Philander, S. G. H., and R. C. Pacanowski, 1981: The response of equatorial oceans to periodic forcing. J. Geophys. Res., 86, 19031916.

, and - 1986a: A model of the seasonal cycle in the tropical Atlantic Ocean. J. Geophys. Res., 91 (C12), 14 192-14 206.

, and - 1986b: The mass and heat budget in a model of the seasonal cycle in the tropical Atlantic Ocean. J. Geophys. Res. 91(C12), $14212-14220$.

Richardson, P. L., and D. Walsh, 1986: Mapping climatological seasonal variations of surface currents in the tropical Atlantic using ship drifts. J. Geophys. Res., 91, 10 537-10 550.

- and G. Reverdin, 1987: Seasonal cycle of velocity in the Atlantic North Equatorial Countercurrent as measured by surface drifters, current meters, and ship drifts. J. Geophys. Res., 92(C4), 36913708 .

Roemmich, D., 1983: The balance of geostrophic and Ekman transports in the tropical Atlantic Ocean. J. Phys. Oceanogr., 13, 1534-1539.

Rosenfeld, L. K., R. L. Molinari, and K. D. Leaman, 1989: Observed and modeled annual cycle of transport in the Straits of Florida and east of Abaco Island, the Bahamas $\left(26.5^{\circ} \mathrm{N}\right) . J$. Geophys. Res., 94(C4), 4867-4878.

Ryther, J. H., D. W. Menzel, and N. Corwin, 1967: Influence of the Amazon River outflow on the ecology of the western tropical Atlantic. J. Mar. Res., 25, 69-83.

Sarmiento, J. L., 1986: On the north and tropical Atlantic heat balance. J. Geophys. Res., 91, $11677-11689$

Schmitz, W. J., and P. L. Richardson, 1991: On the sources of the Florida Current. Deep-Sea Res., 38(Suppl. 1), S379-S409.

Schott, F. A., and C. W. Böning, 1991: The WOCE model in the western equatorial Atlantic: Upper layer circulation. J. Geophys. Res., 96(C4), 6993-7004.

- T. N. Lee, and R. Zantopp, 1988: Variability of structure and transport of the Florida Current in the period range of days to seasonal. J. Phys. Oceanogr., 18, 1209-1230.

Slutz, R. J., S. J. Lubker, J. D. Hiscox, S. D. Woodruff, R. L. Jenne, D. H. Joseph, P. M. Steurer, and J. D. Elms, 1985: Comprehensive ocean-atmosphere data set; Release 1, NOAA Environmental Research Laboratories, Climate Research Program, Boulder, CO, 268 pp. [NTIS PB86-105723.]

Talley, L. D., and M. E. Raymer, 1982: Eighteen degree water variability. J. Mar. Res., 40(Suppl.), 757-775.

Thompson, J., J. Dana, T. L. Townsend, and W. J. Schmitz, Jr., 1991: Model/data comparisons in the North Atlantic: The transport of the Florida Current. Mar. Technol. Soc. Proc., 2, 946-951.

Weingartner, T. J., and R. H. Weisberg, 1991: A description of the annual cycle in sea surface temperature and upper ocean heat in the equatorial Atlantic. J. Phys. Oceanogr., 21, 83-96.

Weisberg, R. H., and T. Y. Tang, 1987: Further studies on the response of the equatorial thermocline in the Atlantic Ocean to the seasonally varying trade winds. J. Geophys. Res., 92(C4), 37093727 .

- and - 1990: A linear analysis of equatorial Atlantic Ocean thermocline variability. J. Phys. Oceanogr., 20, 1813-1825.

- J. H. Hickman, T. Y. Tang, and T. J. Weingartner, 1987: Velocity and temperature observations during the seasonal response of the equatorial Atlantic Experiment at $0^{\circ}, 28^{\circ} \mathrm{W} . J$. Geophys. Res., 92, 5061-5075.

Woodruff, S. D., R. J. Slutz, R. L. Jenne, and P. M. Steurer, 1987: A comprehensive ocean-atmosphere data set. Bull. Amer. Meteor. Soc., 68, 1239-1250.

Worthington, L. V., 1977: The intensification of the Gulf Stream after the winter of 1976-1977. Nature, 270, 415-417. 